\title{
Effects of Ni particle size on amination of monoethanolamine over $\mathrm{Ni}-\mathrm{Re} / \mathrm{SiO}_{2}$ catalysts
}

\author{
Lei Ma a,b,d, Li Yan a,\#, An-Hui Lu ${ }^{b}$, Yunjie Ding a,c,* \\ a Dalian National Laboratory for Clean Energy, Dalian Institute of Chemical Physics, Chinese Academy of Sciences, Dalian 116023, Liaoning, China \\ b State Key Laboratory of Fine Chemicals, School of Chemical Engineering, Dalian University of Technology, Dalian 116024, Liaoning, China \\ c State Key Laboratory of Catalysis, Dalian Institute of Chemical Physics, Chinese Academy of Sciences, Dalian 116023, Liaoning, China \\ $\mathrm{d}$ University of Chinese Academy of Sciences, Beijing 100049, China
}

\section{A R T I C L E I N F O}

\section{Article history:}

Received 24 October 2018

Accepted 8 January 2019

Published 5 April 2019

\section{Keywords:}

Particle size effects

Monoethanolamine

Amination reaction

$\mathrm{Ni}-\mathrm{Re} / \mathrm{SiO}_{2}$

Turn over frequency

\begin{abstract}
A B S T R A C T
$\mathrm{Ni}-\mathrm{Re} / \mathrm{SiO}_{2}$ catalysts with controllable Ni particle sizes $(4.5-18.0 \mathrm{~nm})$ were synthesized to investigate the effects of the particle size on the amination of monoethanolamine (MEA). The catalysts were characterized by various techniques and evaluated for the amination reaction in a trickle bed reactor at $170{ }^{\circ} \mathrm{C}, 8.0 \mathrm{MPa}$, and $0.5 \mathrm{~h}^{-1}$ liquid hourly space velocity of MEA (LHSV MEA) in $\mathrm{NH}_{3} / \mathrm{H}_{2}$ atmosphere. The $\mathrm{Ni}-\mathrm{Re} / \mathrm{SiO}_{2}$ catalyst with the lowest Ni particle size $(4.5 \mathrm{~nm})$ exhibited the highest yield (66.4\%) of the desired amines (ethylenediamine (EDA) and piperazine (PIP)). The results of the analysis show that the turnover frequency of MEA increased slightly (from 193 to $253 \mathrm{~h}^{-1}$ ) as the $\mathrm{Ni}$ particle sizes of the $\mathrm{Ni}-\mathrm{Re} / \mathrm{SiO}_{2}$ catalysts increased from 4.5 to $18.0 \mathrm{~nm}$. Moreover, the product distribution could be adjusted by varying the Ni particle size. The ratio of primary to secondary amines increased from 1.0 to 2.0 upon increasing the Ni particle size from 4.5 to $18.0 \mathrm{~nm}$. Further analyses reveal that the $\mathrm{Ni}$ particle size influenced the electronic properties of surface $\mathrm{Ni}$, which in turn affected the adsorption of MEA and the reaction pathway of MEA amination. Compared to those of small Ni particles, large particles possessed a higher proportion of high-coordinated terrace $\mathrm{Ni}$ sites and a higher surface electron density, which favored the amination of MEA and $\mathrm{NH}_{3}$ to form EDA.
\end{abstract}

(c) 2019, Dalian Institute of Chemical Physics, Chinese Academy of Sciences. Published by Elsevier B.V. All rights reserved.

\section{Introduction}

As important fine chemicals, ethylene amines are widely used as solvents, stabilizers, and for the synthesis of pharmaceuticals, chelating agents, resins, surfactants, and fabric softeners. In chemical industry production [1-4], the amination of monoethanolamine (MEA) represents an economical and environmentally benign method to prepare valuable ethylene amines, mainly including ethylenediamine (EDA) and pipera- zine (PIP). The amination reaction of MEA is generally driven by $\mathrm{Ni}-$, $\mathrm{Co}-$, or $\mathrm{Cu}$-based metallic catalysts via a borrowing hydrogen mechanism (Scheme 1) [5-8]: initially, MEA is dehydrogenated to form a 2-aminoacetaldehyde compound; next, an imine is formed through condensation of the aldehyde with ammonia or another MEA molecule; finally, the intermediate imine is reduced to ethylene amines. During the catalytic amination process (Scheme 2), various competitive and consecutive reactions can take place through the participation of prod-

\footnotetext{
* Corresponding author. Tel/Fax: +86-411-84379143; E-mail: dyj@dicp.ac.cn

\# Corresponding author. Tel/Fax: +86-411-84379055; E-mail: yanli@dicp.ac.cn

This work was supported by the National Natural Science Foundation of China (21273227) and Strategic Priority Research Program of Chinese Academy of Sciences (XDB17000000).

DOI: S1872-2067(19)63302-4 | http://www.sciencedirect.com/science/journal/18722067 | Chin. J. Catal., Vol. 40, No. 4, April 2019
} 


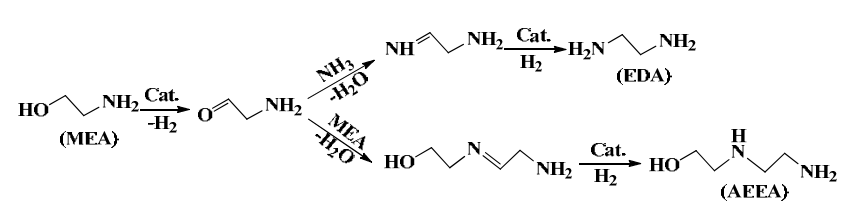

Scheme 1. Reaction mechanism for MEA amination.

uct amines in the condensation step. These reactions unavoidably generate a variety of by-products, including $N$-(2-aminoethyl)ethanolamine $N$-aminoethylpiperazine (AEP),

(AEEA), $N$-(2-hydroxyethyl)piperazine (HEP). The formation of by-products would result in economic losses and product separation issues. The development of efficient catalysts with a high yield of desired amines (EDA and PIP) is thus an important and challenging research target.

In the case of supported metal catalysts, the surface chemical properties and electronic structure of the metal particles are influenced by their size [9-17]. Upon increasing the size of the metal particles, the fraction of terrace sites increases linearly, while the fraction of step/corner sites decreases slowly. These changes in the distribution of surface sites may alter the coordination environment of surface metals, thus influencing the adsorption and activation capabilities of the catalysts. The effects of the metal particle size in catalysis have been investigated for many structure-sensitive reactions. Typically, for the Pd-catalyzed dehydrogenation of alcohols, Wang et al. [11] concluded that a suitable ratio of surface atoms (terrace Pd) to coordinatively unsaturated atoms (edge and corner Pd) favors the adsorption and $\beta-\mathrm{H}$ activation steps. Jensen et al. [18] studied the effects of the $\mathrm{Ni}$ particle size of $\mathrm{Ni} / \mathrm{SiO}_{2}$ catalyst in the hydrodeoxygenation of phenol. They found that deoxygenation and hydrogenation reactions are facilitated on step/corner and terrace Ni sites, respectively. Zhu et al. [9] investigated the influence of the Ni particle size in $m$-cresol hydrodeoxygenation. They reported that the selectivities to products are influenced by the $\mathrm{Ni}$ particle size of $\mathrm{Ni} / \mathrm{SiO}_{2}$ catalysts. For the amination reaction, a few papers on particle size effects have been reported. Shimizu et al. [19] reported the $N^{\prime}$-alkylation of amines with alcohols on $\mathrm{Ni} / \mathrm{Al}_{2} \mathrm{O}_{3}$ catalysts in a slurry reactor at $144^{\circ} \mathrm{C}$. They concluded that the turnover frequency (TOF) increases with a decrease in $\mathrm{Ni}$ particle size, and low-coordinated $\mathrm{Ni}$ combined with acid-base sites represents the active phase for the dehydrogenation and hydrogen transfer steps. In catalytic amination reactions, the effects of the metal particle size may be influenced by various factors, including catalyst support, particle size distribution, reaction substrate, and reaction conditions. Therefore, previous studies of structure-activity relationships have not yet reached a common conclusion. Moreover, to the best of our knowledge, the effects of the metal particle size on the product distribution of the amination of alcohol amines have never been investigated.

In this work, $\mathrm{SiO}_{2}$ was selected as inert support in order to avoid or reduce the complications associated with the interaction between metal and support. $\mathrm{Ni}-\mathrm{Re} / \mathrm{SiO}_{2}$ catalysts $(\mathrm{Ni} 20$ $w t \%$, Re 1.5 wt\%) with a wide range of $\mathrm{Ni}$ particle sizes (4.5-18.0 nm) were prepared and characterized by $\mathrm{N}_{2}$ physisorption, $\mathrm{H}_{2}$ temperature programmed reduction ( $\left.\mathrm{H}_{2}-\mathrm{TPR}\right)$, $\mathrm{H}_{2}$ temperature programmed desorption ( $\mathrm{H}_{2}$-TPD), X-ray diffraction (XRD), transmission electron microscopy (TEM), $\mathrm{H}_{2}$ chemisorption, as well as Fourier transform infrared (FT-IR) spectroscopy measurements of adsorbed CO and MEA. We investigated the MEA amination over supported Ni-Re catalysts in a trickle-bed reactor in order to understand the effects of the $\mathrm{Ni}$ particle size on the catalyst activity and selectivity to product amines.

\section{Experimental}

\subsection{Catalyst preparation}

$\mathrm{Ni}-\mathrm{Re} / \mathrm{SiO}_{2}$ catalysts (Ni $20 \mathrm{wt} \%$, Re $1.5 \mathrm{wt} \%$ ) were prepared by incipient-wetness impregnation. Silica (Qingdao Haiyang Chemical Co., Ltd., China) was used as support while $\mathrm{Ni}\left(\mathrm{NO}_{3}\right)_{2} \cdot 6 \mathrm{H}_{2} \mathrm{O}$ (99.9\% purity) and $\mathrm{NH}_{4} \mathrm{ReO}_{4}$ (99.99\% purity) were employed as metal precursors. After impregnation, the materials were dried at $120{ }^{\circ} \mathrm{C}$ for $4 \mathrm{~h}$. The following $\mathrm{Ni}-\mathrm{Re} / \mathrm{SiO}_{2}$ catalysts, with varying particle sizes, were prepared under different calcination atmospheres and reduction temperatures.

Catalyst 1: The materials were calcined in a tubular oven under a flow of $\mathrm{NO} / \operatorname{Ar}(1 \% \mathrm{v} / \mathrm{v})$ at $450{ }^{\circ} \mathrm{C}$, corresponding to a space velocity of about $8.4 \times 10^{3} \mathrm{~h}^{-1}$. The calcined catalysts were denoted as $\mathrm{Ni}-\mathrm{Re} / \mathrm{SiO}_{2}-\mathrm{NO}$. Before reaction, the $\mathrm{Ni}-\mathrm{Re} / \mathrm{SiO}_{2}$-NO catalysts were reduced in situ in a trickle-bed reactor under a $\mathrm{H}_{2}$ flow of $100 \mathrm{ml} \cdot \mathrm{min}^{-1}$ for $4 \mathrm{~h}$ at $440{ }^{\circ} \mathrm{C}$. The obtained catalysts were denoted as $\mathrm{Ni}-\mathrm{Re} / \mathrm{SiO}_{2}-4.5$.

Catalyst 2: The materials were calcined in a tubular oven under a flow of $\mathrm{Ar}$ at $450{ }^{\circ} \mathrm{C}$, corresponding to a space velocity of about $3.6 \times 10^{3} \mathrm{~h}^{-1}$. The calcined catalysts were denoted as

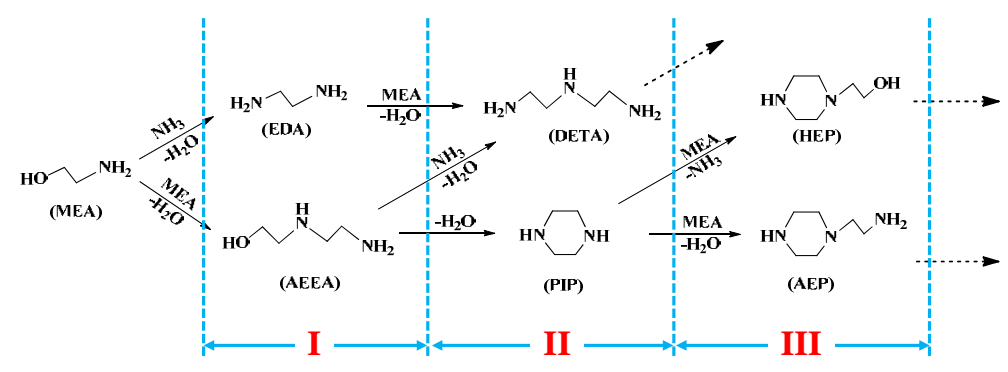

Scheme 2. Main reaction pathways of MEA amination on $\mathrm{Ni}-\mathrm{Re} / \mathrm{SiO}_{2}$ catalysts. I, II, and III represent the amines produced under different reaction depth. 
$\mathrm{Ni}-\mathrm{Re} / \mathrm{SiO}_{2}-\mathrm{Ar}$. Before reaction, the obtained $\mathrm{Ni}-\mathrm{Re} / \mathrm{SiO}_{2}-\mathrm{Ar}$ catalysts were reduced in situ in a trickle-bed reactor under a $\mathrm{H}_{2}$ flow of $100 \mathrm{ml} \cdot \mathrm{min}^{-1}$ for $4 \mathrm{~h}$ at $440^{\circ} \mathrm{C}$. The obtained catalysts were denoted as $\mathrm{Ni}-\mathrm{Re} / \mathrm{SiO}_{2}-10.5$.

Catalyst 3: The materials were calcined in a tubular oven under a still air atmosphere at $450{ }^{\circ} \mathrm{C}$. The calcined catalysts were denoted as $\mathrm{Ni}-\mathrm{Re} / \mathrm{SiO}_{2}$-Air. Before reaction, the obtained $\mathrm{Ni}-\mathrm{Re} / \mathrm{SiO}_{2}$-Air catalysts were reduced in situ in a trickle-bed reactor under a $\mathrm{H}_{2}$ flow of $100 \mathrm{ml} \cdot \mathrm{min}^{-1}$ for $4 \mathrm{~h}$ at $440{ }^{\circ} \mathrm{C}$. The obtained catalysts were denoted as $\mathrm{Ni}-\mathrm{Re} / \mathrm{SiO}_{2}-14.6$.

Catalyst 4: The materials were calcined in a tubular oven under a still air atmosphere at $450{ }^{\circ} \mathrm{C}$. The calcined catalysts were denoted as $\mathrm{Ni}-\mathrm{Re} / \mathrm{SiO}_{2}$-Air. Before reaction, the obtained $\mathrm{Ni}-\mathrm{Re} / \mathrm{SiO}_{2}$-Air catalysts were reduced in situ in a trickle-bed reactor under a $\mathrm{H}_{2}$ flow of $100 \mathrm{ml} \cdot \mathrm{min}^{-1}$ for $4 \mathrm{~h}$ at $640{ }^{\circ} \mathrm{C}$. The obtained catalysts were denoted as $\mathrm{Ni}-\mathrm{Re} / \mathrm{SiO}_{2}-18.0$.

Monometallic $\mathrm{Ni} / \mathrm{SiO}_{2}$ (Ni $20 \mathrm{wt} \%$ ) and $\mathrm{Re} / \mathrm{SiO}_{2}$ ( $\mathrm{Re} 1.5$ $\mathrm{wt} \%$ ) catalysts were also prepared for comparison. The preparation process was the same as that employed for the $\mathrm{Ni}-\mathrm{Re} / \mathrm{SiO}_{2}-14.6$ catalyst.

\subsection{Catalyst characterization}

$\mathrm{N}_{2}$ physisorption isotherms were recorded on a Quantachrome Autosorb instrument. Before the measurements, the samples were outgassed at $300{ }^{\circ} \mathrm{C}$ for $3 \mathrm{~h}$ under vacuum. The total specific surface area and pore size distribution were calculated by Brunauer-Emmet-Teller (BET) and Barrett-Joyner-Halenda (BJH) analyses. The total pore volume was determined from the amount of $\mathrm{N}_{2}$ adsorbed at a $P / P_{0}$ ratio of 0.99 .

The metal loadings of $\mathrm{Ni}$ or $\mathrm{Re}$ in the $\mathrm{Ni}-\mathrm{Re} / \mathrm{SiO}_{2}$ catalysts were determined by inductively coupled plasma optical emission spectroscopy (ICP-OES). A Perkin Elmer Optima 7300 DV spectrometer was used for elemental detection.

$\mathrm{H}_{2}$-TPR and $\mathrm{H}_{2}$-TPD measurements were carried out using an Altamira Instruments AMI-300 analyzer equipped with a thermal conductivity detector (TCD). For the $\mathrm{H}_{2}$-TPR measurements, about $100 \mathrm{mg}$ of calcined catalysts were placed in a quartz reactor. To remove impurities, the catalysts were treated in a flow of $\mathrm{Ar}$ at $400{ }^{\circ} \mathrm{C}$ for $0.5 \mathrm{~h}$, followed by cooling to 50 ${ }^{\circ} \mathrm{C}$. Next, the temperature was increased to $900{ }^{\circ} \mathrm{C}$ at a heating rate of $10{ }^{\circ} \mathrm{C} \cdot \mathrm{min}^{-1}$ in a $30 \mathrm{ml} \cdot \mathrm{min}^{-1}$ flow of $\mathrm{H}_{2} / \mathrm{Ar}(10 \% \mathrm{v} / \mathrm{v})$. The amount of $\mathrm{H}_{2}$ consumption was measured by the TCD. For the $\mathrm{H}_{2}$-TPD measurements, the catalysts were reduced for $4 \mathrm{~h}$ in a $\mathrm{H}_{2}$ flow, followed by cooling to $30^{\circ} \mathrm{C}$ in Ar flow. Afterward, the catalysts were exposed to a flow of $\mathrm{H}_{2} / \mathrm{Ar}(10 \% \mathrm{v} / \mathrm{v})$ for $1 \mathrm{~h}$ at $30^{\circ} \mathrm{C}$. After being purged in $\mathrm{Ar}$ flow for $30 \mathrm{~min}$ at $40{ }^{\circ} \mathrm{C}$, the catalysts were heated linearly at $10{ }^{\circ} \mathrm{C} \cdot \mathrm{min}^{-1}$ to $800^{\circ} \mathrm{C}$ in $\mathrm{Ar}$ flow $\left(30 \mathrm{ml} \cdot \mathrm{min}^{-1}\right)$. The amount of desorbed $\mathrm{H}_{2}$ was measured with the TCD.

The XRD patterns of the reduced $\mathrm{Ni}-\mathrm{Re} / \mathrm{SiO}_{2}$ catalysts were recorded using a PANalytical X'Pert PRO diffractometer equipped with a $\mathrm{Cu} K_{\alpha}$ radiation source. After reduction, the catalysts were passivated by exposing them to $\mathrm{N}_{2} \mathrm{O} / \mathrm{He}(10 \%$ $v / v$ ) at $70{ }^{\circ} \mathrm{C}$ for $1 \mathrm{~h}$. The patterns were recorded with a step size of $0.013^{\circ}$ and a scan speed of $0.04^{\circ} \mathrm{s}^{-1}$.
TEM micrographs of the $\mathrm{Ni}-\mathrm{Re} / \mathrm{SiO}_{2}$ catalysts were acquired in bright-field mode using a Tecnai G2 F30 S-Twin electron microscope operated at $300 \mathrm{kV}$. The reduced catalysts were passivated by exposing them to $\mathrm{N}_{2} \mathrm{O} / \mathrm{He}(10 \% \mathrm{v} / \mathrm{v})$ at $70{ }^{\circ} \mathrm{C}$ for $1 \mathrm{~h}$. The samples were prepared by dispersion of the catalysts powder on a carbon film-supported $\mathrm{Cu}$ grid. The particle size distribution was determined by measuring the sizes of more than 200 particles in different selected regions of the TEM images.

$\mathrm{H}_{2}$ chemisorption experiments were performed by a static chemisorption method using a Quantachrome Autosorb instrument. The experiment was carried out using $\sim 0.5 \mathrm{~g}$ of the $\mathrm{Ni}-\mathrm{Re} / \mathrm{SiO}_{2}$ catalysts. The samples were reduced in situ in a flow of $\mathrm{H}_{2}$. After reduction, the sample was evaluated for $1 \mathrm{~h}$ to remove the residual $\mathrm{H}_{2}$ and cooled to room temperature. The $\mathrm{H}_{2}$ adsorption isotherms were measured at room temperature. The irreversible $\mathrm{H}_{2}$ uptake, determined from the total and reversible $\mathrm{H}_{2}$ uptakes, was used to calculate the amount of surface metal sites [20]. The $\mathrm{H} / \mathrm{Ni}$ ratio in the chemisorption experiments was taken as 1 . No detectable $\mathrm{H}_{2}$ uptake was observed on the monometallic $\mathrm{Re} / \mathrm{SiO}_{2}$ catalyst.

CO- and MEA-adsorbed FT-IR measurements were recorded on a Thermo Scientific Nicolet iS50 spectrometer, equipped with a mercury-cadmium-tellurium (MCT) detector and operated at a resolution of $4 \mathrm{~cm}^{-1}$. For the CO-adsorbed FT-IR measurements, 15-20 mg powder samples were compressed into a self-supporting wafer and reduced in a cell with $\mathrm{H}_{2}$ for 1 h. Following reduction, the cell was evacuated to $10^{-2} \mathrm{~Pa}$ and cooled to room temperature. Background spectra were collected before CO adsorption. After cooling, CO gas was introduced into the cell for $20 \mathrm{~min}$ at room temperature. Finally, the cell was evacuated again and the spectra were recorded against a background of the sample. For the MEA-adsorbed FT-IR measurements, the cell was evacuated to approximately 40-50 $\mathrm{Pa}$ and cooled to $50{ }^{\circ} \mathrm{C}$ after reduction. The IR spectra of the samples were recorded as backgrounds. MEA vapor was introduced in the cell at $50{ }^{\circ} \mathrm{C}$ for about $10 \mathrm{~min}$. After MEA adsorption, physically adsorbed MEA was desorbed in vacuum (40-50 $\mathrm{Pa}$ ) at $50{ }^{\circ} \mathrm{C}$ for about $10 \mathrm{~min}$. Next, the temperature of the cell was increased at a heating rate of $10{ }^{\circ} \mathrm{C} \cdot \mathrm{min}^{-1}$ and the spectra of the samples were recorded.

X-ray photoelectron spectroscopy (XPS) spectra of the catalysts were recorded using a Thermo ESCALAB 250Xi spectrometer. A monochromatic Al $K_{\alpha} \mathrm{X}$-ray source of $15 \mathrm{kV}$ was employed. The ex situ reduced powder catalysts were pressed into self-supported pellets. The chamber was evacuated to about $7.1 \times 10^{-5} \mathrm{~Pa}$. The binding energy (BE) values were referred to the Si $2 p$ line at $103.4 \mathrm{eV}$.

\subsection{Activity measurements}

The catalytic performance of the $\mathrm{Ni}-\mathrm{Re} / \mathrm{SiO}_{2}$ catalysts for MEA amination was evaluated in a trickle-bed reactor. As de-

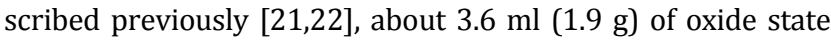
catalysts were placed in the center of a stainless steel reaction tube, and the residual space was filled with silica sand. Before reaction, the catalyst was reduced in situ. Following reduction, 
the temperature was decreased to the reaction temperature. The feed, consisting of MEA and liquid $\mathrm{NH}_{3}$ (molar ratio 1:10), was injected into the reactor by a syringe pump. According to the industrial production conditions, MEA amination was performed at $170{ }^{\circ} \mathrm{C}$ under a total pressure of $8.0 \mathrm{MPa}$, a liquid hourly space velocity (LHSVMEA) of $0.5 \mathrm{~h}^{-1}$, and a $\mathrm{H}_{2}$ gas hourly space velocity (GHSV) of $60 \mathrm{~h}^{-1}$. The products were collected at intervals of about 6-12 h and analyzed using a gas chromatograph (Agilent 7890) fitted with a flame ionization detector and a DB-35 capillary column. The conversion and selectivity were calculated using the following equations:

$$
\begin{gathered}
\text { Conversion }_{\mathrm{MEA}}(\%)=\frac{n_{\mathrm{MEA}, \text { in }}-n_{\mathrm{MEA}, \text { out }}}{n_{\mathrm{MEA}, \mathrm{in}}} \times 100 \\
\text { Selectivity }_{\mathrm{i}}(\%)=\frac{n_{\mathrm{i}}}{\sum n_{\mathrm{i}}} \times 100
\end{gathered}
$$

where $n_{\text {MEA,in }}$ and $n_{\text {MEA,out }}$ are the number of moles of MEA initially added and remaining in the products, respectively, while $n_{\mathrm{i}}$ represents the molar amount of compound $\mathrm{i}$ in the products.

In order to determine the TOF of MEA, the amount of used catalysts was varied in order to keep the conversion at a low level (below 20\%). The effects of internal and external diffusion were excluded in the experiments. The reaction temperature and pressure remained the same, while the LHSV MEA was varied from 3.0 to $17.9 \mathrm{~h}^{-1}$. The TOF values of MEA were calculated using the following equations:

$$
\begin{gathered}
r\left(\mu \mathrm{mol} \cdot \mathrm{g}_{\text {cat. }}^{-1} \cdot \mathrm{h}^{-1}\right)=\frac{n_{\mathrm{MEA}, \text { in }}-n_{\mathrm{MEA}, \mathrm{out}}}{m_{\text {cat. }} \cdot t} \\
\operatorname{TOF}\left(\mathrm{h}^{-1}\right)=\frac{n_{\mathrm{MEA}, \text { in }}-n_{\mathrm{MEA}, \text { out }}}{n_{\mathrm{Ni}} \cdot t}
\end{gathered}
$$

where $r$ is the intrinsic reaction rate of catalyst, $m_{\text {cat. }}$ denotes the mass of catalysts, $t$ is the reaction time, and $n_{\mathrm{Ni}}$ represents the molar amount of surface $\mathrm{Ni}$ sites measured by $\mathrm{H}_{2}$ chemisorption.

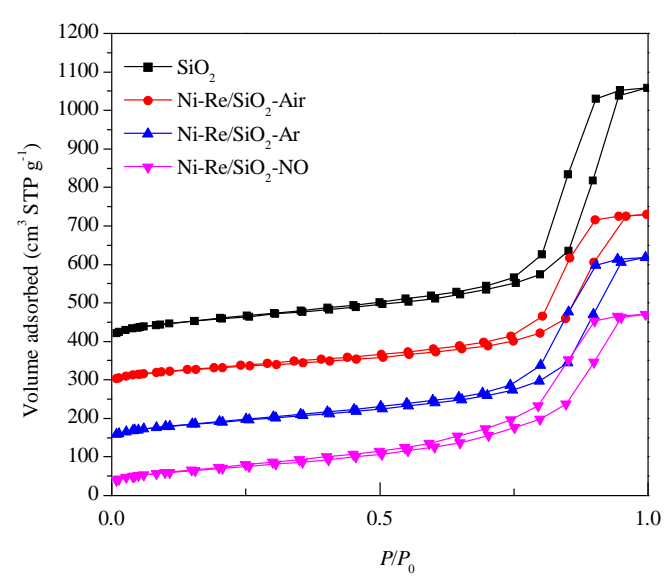

Fig. 1. $\mathrm{N}_{2}$ adsorption-desorption isotherms of $\mathrm{SiO}_{2}$ support and calcined $\mathrm{Ni}-\mathrm{Re} / \mathrm{SiO}_{2}-\mathrm{Air}, \mathrm{Ni}-\mathrm{Re} / \mathrm{SiO}_{2}-\mathrm{Ar}$, and $\mathrm{Ni}-\mathrm{Re} / \mathrm{SiO}_{2}-\mathrm{NO}$ catalysts. The isotherms of $\mathrm{SiO}_{2}, \mathrm{Ni}-\mathrm{Re} / \mathrm{SiO}_{2}$-Air, and $\mathrm{Ni}-\mathrm{Re} / \mathrm{SiO}_{2}$-Ar were offset vertically by 380,268 , and $120 \mathrm{~cm}^{3} \cdot \mathrm{g}^{-1}$ (STP), respectively.
Table 1

Physical properties of $\mathrm{SiO}_{2}$ support and calcined $\mathrm{Ni}-\mathrm{Re} / \mathrm{SiO}_{2}$ catalysts.

\begin{tabular}{lccc}
\hline Catalyst & $\begin{array}{c}\text { Surface area } \\
\left(\mathrm{m}^{2} \cdot \mathrm{g}^{-1}\right)\end{array}$ & $\begin{array}{c}\text { Pore volume } \\
\left(\mathrm{ml} \cdot \mathrm{g}^{-1}\right)\end{array}$ & $\begin{array}{c}\text { Pore diameter } \\
(\mathrm{nm})\end{array}$ \\
\hline $\mathrm{SiO}_{2}$ & 285 & 1.1 & 12.5 \\
$\mathrm{Ni}-\mathrm{Re} / \mathrm{SiO}_{2}-\mathrm{NO}$ & 259 & 0.8 & 12.3 \\
$\mathrm{Ni}-\mathrm{Re} / \mathrm{SiO}_{2}-\mathrm{Ar}$ & 253 & 0.7 & 12.5 \\
$\mathrm{Ni}-\mathrm{Re} / \mathrm{SiO}_{2}-\mathrm{Air}$ & 226 & 0.7 & 12.6 \\
\hline
\end{tabular}

a Calculated by the BET equation at a relative pressure $\left(P / P_{0}\right)$ of $0.05-0.30$; ${ }^{\text {b }}$ Total pore volume at $P / P_{0} \sim 0.990$; ${ }^{\mathrm{c}}$ Calculated by the $\mathrm{BJH}$ method using the desorption branch; ${ }^{\mathrm{d}}$ Determined by ICP-OES analysis.

\section{Results and discussion}

\subsection{Physicochemical properties of calcined $\mathrm{Ni}-\mathrm{Re} / \mathrm{SiO}_{2}$ catalysts}

The porous nature of the $\mathrm{SiO}_{2}$ carrier and the calcined $\mathrm{Ni}-\mathrm{Re} / \mathrm{SiO}_{2}$ catalysts was confirmed by the analysis of $\mathrm{N}_{2}$ adsorption-desorption data. The $\mathrm{N}_{2}$ adsorption-desorption isotherms are shown in Fig. 1. All samples exhibited type IV isotherms with H1-shaped hysteresis loops, indicating the presence of uniform cylindrical mesoporous channels. The values of the BET surface area, total pore volume, and pore diameter are listed in Table 1. The $\mathrm{SiO}_{2}$ support exhibited a surface area of $285 \mathrm{~m}^{2} \cdot \mathrm{g}^{-1}$, a pore volume of $1.1 \mathrm{~cm}^{3} \cdot \mathrm{g}^{-1}$, and a pore diameter around $12.5 \mathrm{~nm}$. After being impregnated with metal species and calcined under different atmospheres, the $\mathrm{Ni}-\mathrm{Re} / \mathrm{SiO}_{2}$ catalysts showed surface areas in the range of $226-259 \mathrm{~m}^{2} \cdot \mathrm{g}^{-1}$. The pore volume and diameter were around $0.7-0.8 \mathrm{ml} \cdot \mathrm{g}^{-1}$ and 12.3-12.6 nm, respectively. The decrease in surface area and pore volume was due to the partial blockage of the mesopores after Ni and Re were loaded on the support.

The interaction between metal species and $\mathrm{SiO}_{2}$ support was investigated using $\mathrm{H}_{2}$-TPR measurements. As shown in Fig. 2, the monometallic $\mathrm{Re} / \mathrm{SiO}_{2}$ sample displayed a broad $\mathrm{H}_{2}$ consumption peak in the range of $330-420{ }^{\circ} \mathrm{C}$, corresponding to the reduction process of $\mathrm{ReO}_{x}$ with different oxidation states $[21,23]$. The $\mathrm{Ni} / \mathrm{SiO}_{2}$ sample showed two reduction peaks: (I) a broad peak around $412^{\circ} \mathrm{C}$ ascribed to the reduction of bulk NiO particles weakly interacting with $\mathrm{SiO}_{2}$, and (II) a small peak at

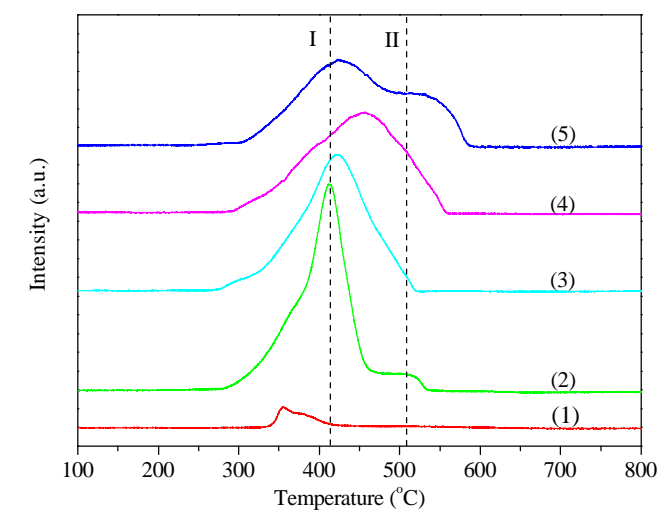

Fig. 2. $\mathrm{H}_{2}$-TPR profiles of $\mathrm{Re} / \mathrm{SiO}_{2}$ (1); $\mathrm{Ni} / \mathrm{SiO}_{2}(2)$; $\mathrm{Ni}-\mathrm{Re} / \mathrm{SiO}_{2}-\mathrm{Air}(3)$; $\mathrm{Ni}-\mathrm{Re} / \mathrm{SiO}_{2}-\mathrm{Ar}(4)$; and $\mathrm{Ni}-\mathrm{Re} / \mathrm{SiO}_{2}-\mathrm{NO}(5)$ catalysts. 
$510{ }^{\circ} \mathrm{C}$ that was attributed to highly dispersed $\mathrm{Ni}^{2+}$ species that were difficult to reduce [24-27]. After being modified with the Re promoter, the $\mathrm{Ni}-\mathrm{Re} / \mathrm{SiO}_{2}$-Air catalyst showed a broad peak at $420{ }^{\circ} \mathrm{C}$. Among the $\mathrm{Ni}-\mathrm{Re} / \mathrm{SiO}_{2}$ catalysts pretreated in a flow of different gases, the $\mathrm{Ni}-\mathrm{Re} / \mathrm{SiO}_{2}-\mathrm{Ar}$ sample showed a reduction peak at $455^{\circ} \mathrm{C}$, while the $\mathrm{Ni}-\mathrm{Re} / \mathrm{SiO}_{2}$-NO catalyst displayed a reduction peak at $420^{\circ} \mathrm{C}$ and a shoulder at $530^{\circ} \mathrm{C}$. A shift of the reduction peak to higher temperature was observed in the $\mathrm{Ni}-\mathrm{Re} / \mathrm{SiO}_{2}$ catalysts pretreated using either $\mathrm{Ar}$ or NO. This phenomenon may be attributed to the stronger interaction between $\mathrm{NiO}$ and the $\mathrm{SiO}_{2}$ support, due to the high dispersion of $\mathrm{Ni}$ species after calcination under dynamic Ar/NO atmosphere [28-31]. The $\mathrm{H}_{2}$-TPR results indicate that the calcination atmosphere could influence the reducibility of $\mathrm{NiO}$ species and the interaction between $\mathrm{NiO}$ and support in $\mathrm{Ni}-\mathrm{Re} / \mathrm{SiO}_{2}$ catalysts.

\subsection{Particle size characterization for reduced catalysts}

The crystal phase and dispersion of the Ni particles in the reduced catalysts were further investigated by XRD and TEM measurements. The XRD patterns are shown in Fig. 3. The pattern of monometallic $\mathrm{Ni} / \mathrm{SiO}_{2}$ is also shown for comparison. The $\mathrm{Ni} / \mathrm{SiO}_{2}$ catalyst exhibited three peaks at $44.5^{\circ}, 51.9^{\circ}$, and $76.4^{\circ}$, which are characteristics of the (111), (200), and (220) crystal planes of metallic $\mathrm{Ni}$ (JCPDS 65-2865). In the $\mathrm{Ni}-\mathrm{Re} / \mathrm{SiO}_{2}$ catalysts, the introduction of Re did not affect the position of the $\mathrm{Ni}$ peaks. However, the $\mathrm{Ni}-\mathrm{Re} / \mathrm{SiO}_{2}$ catalysts that were thermally treated with different calcination atmospheres or reduction temperatures displayed different peak intensities, indicating different average crystallite sizes of the Ni particles in the four $\mathrm{Ni}-\mathrm{Re} / \mathrm{SiO}_{2}$ catalysts. Moreover, as shown in Fig. 3, no peaks corresponding to Re species (JCPDS 65-7974) were detected in any of the $\mathrm{Ni}-\mathrm{Re} / \mathrm{SiO}_{2}$ catalysts. This result could be ascribed to the low loading and high dispersion of the Re species. The Ni
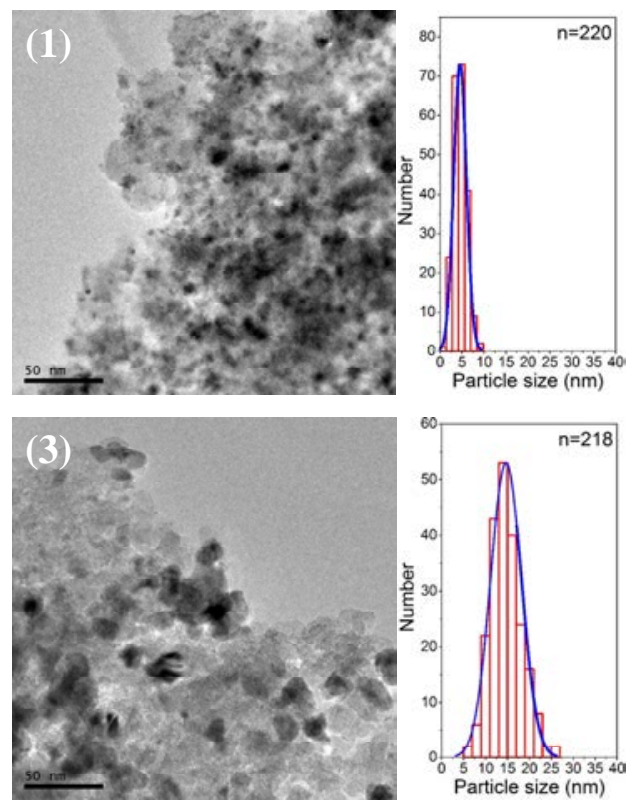

Fig. 4. TEM images and particle size distributions of reduced catalysts. $\mathrm{Ni}-\mathrm{Re} / \mathrm{SiO}_{2}-18.0$.

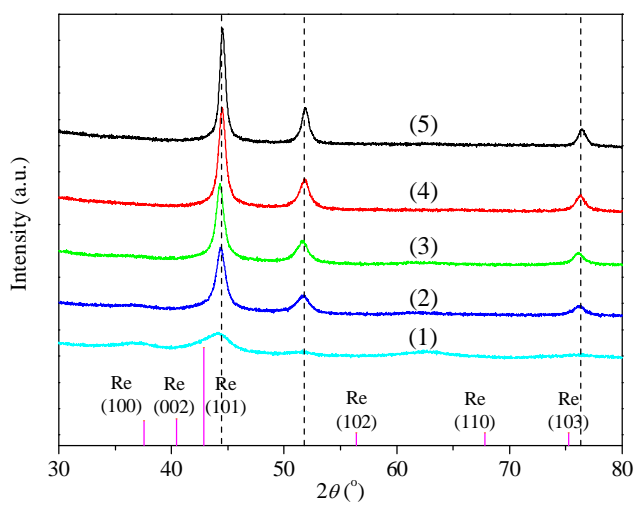

Fig. 3. $\mathrm{XRD}$ patterns of reduced catalysts. (1) $\mathrm{Ni}-\mathrm{Re} / \mathrm{SiO}_{2}-4.5$; (2) $\mathrm{Ni}-\mathrm{Re} / \mathrm{SiO}_{2}-10.5$; (3) Ni-Re/SiO $2-14.6$; (4) Ni-Re/SiO $2-18.0$; (5) Ni/SiO 2 . The Re diffraction lines are also shown as reference.

particle size distribution of the reduced $\mathrm{Ni}-\mathrm{Re} / \mathrm{Al}_{2} \mathrm{O}_{3}$ catalysts was analyzed by TEM. The corresponding images are shown in Fig. 4 and the average particle sizes are listed in Table 2. The high-resolution TEM image of a metal particle in $\mathrm{Ni}-\mathrm{Re} / \mathrm{SiO}_{2}-10.5$ is shown in the inset of Fig. 4(2). The metal particle exhibited an interplanar spacing of $0.206 \mathrm{~nm}$, which was assigned to the lattice fringe of the $\mathrm{Ni}(111)$ plane. As shown in Fig. 4, the size distributions obtained from Gaussian fitting confirmed that the Ni particles were uniformly dispersed on the $\mathrm{SiO}_{2}$ surface. The TEM results indicate that $\mathrm{Ni}-\mathrm{Re} / \mathrm{SiO}_{2}$ catalysts with various $\mathrm{Ni}$ particles sizes $(4.5-18.0 \mathrm{~nm})$ were successfully synthesized. The number of surface $\mathrm{Ni}$ sites and the metal dispersion values were calculated from the $\mathrm{H}_{2}$ chemisorption data and are summarized in Table 2. It should be noted that $\mathrm{H}_{2}$ chemisorption was not detected on monometallic $\mathrm{Re} / \mathrm{SiO}_{2}$. Therefore, the $\mathrm{H}_{2}$ consumption on the $\mathrm{Ni}-\mathrm{Re} / \mathrm{SiO}_{2}$ catalysts was used determine the number of surface Ni sites. For
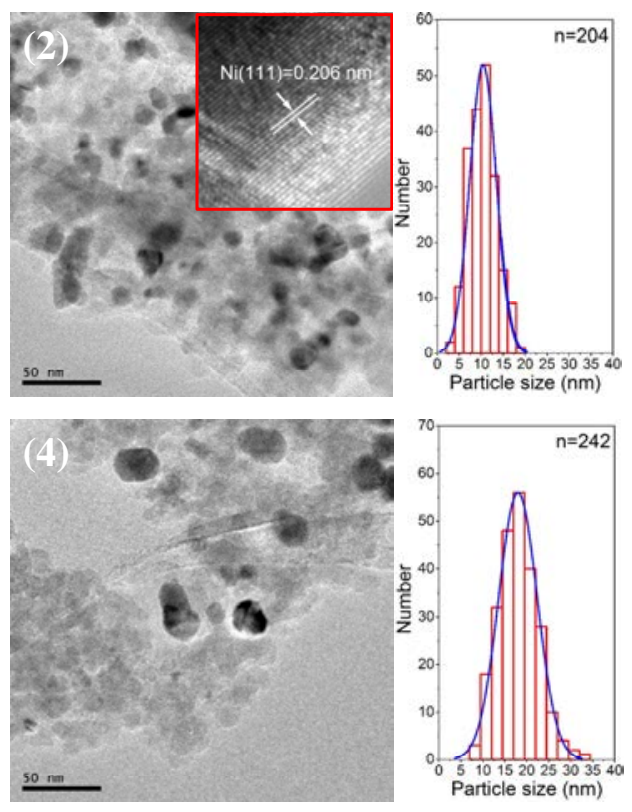

(1) $\mathrm{Ni}-\mathrm{Re} / \mathrm{SiO}_{2}-4.5$; (2) $\mathrm{Ni}-\mathrm{Re} / \mathrm{SiO}_{2}-10.5$; (3) $\mathrm{Ni}-\mathrm{Re} / \mathrm{SiO}_{2}-14.6$; and (4) 
Table 2

Particle size, surface $\mathrm{Ni}$ sites, and $\mathrm{Ni}$ dispersion values of reduced $\mathrm{Ni}-\mathrm{Re} / \mathrm{SiO}_{2}$ catalysts.

\begin{tabular}{|c|c|c|c|c|c|c|}
\hline \multirow{2}{*}{ Catalyst } & \multicolumn{2}{|c|}{ Loading a (wt\%) } & \multicolumn{2}{|c|}{ Particle size $^{\mathrm{b}}(\mathrm{nm})$} & \multirow{2}{*}{ Surface Ni sites ${ }^{c}\left(\mu \mathrm{mol} \cdot \mathrm{g}_{\text {cat. }^{-1}}\right)$} & \multirow{2}{*}{ Ni dispersion ${ }^{\mathrm{c}}(\%)$} \\
\hline & $\mathrm{Ni}$ & $\operatorname{Re}$ & Fresh & Spent & & \\
\hline $\mathrm{Ni}-\mathrm{Re} / \mathrm{SiO}_{2}-4.5$ & 19.6 & 1.4 & 4.5 & 5.2 & 424.6 & 12.7 \\
\hline $\mathrm{Ni}-\mathrm{Re} / \mathrm{SiO}_{2}-10.5$ & 19.2 & 1.4 & 10.5 & 11.1 & 181.0 & 5.5 \\
\hline $\mathrm{Ni}-\mathrm{Re} / \mathrm{SiO}_{2}-14.6$ & 19.7 & 1.4 & 14.6 & 15.0 & 108.9 & 3.1 \\
\hline $\mathrm{Ni}-\mathrm{Re} / \mathrm{SiO}_{2}-18.0$ & 20.8 & 1.5 & 18.0 & 18.2 & 64.1 & 1.8 \\
\hline
\end{tabular}

a Obtained from ICP-OES results; ${ }^{\mathrm{b}}$ Calculated from TEM images; ${ }^{\mathrm{c}}$ Calculated from $\mathrm{H}_{2}$ chemisorption results.

the $\mathrm{Ni}-\mathrm{Re} / \mathrm{SiO}_{2}$ catalysts, this number increased by about seven times (from 64.1 to $424.6 \mu \mathrm{mol} \cdot \mathrm{g}_{\mathrm{cat}^{-}}{ }^{-1}$ ) as the Ni particle size decreased from 18.0 to $4.5 \mathrm{~nm}$. This result could be ascribed to the enhanced $\mathrm{Ni}$ dispersion in $\mathrm{Ni}-\mathrm{Re} / \mathrm{SiO}_{2}$ catalysts calcined in a flow of either Ar or NO [28,29].

\subsection{MEA amination results}

The MEA amination reactions were carried out in a trickle-bed reactor at $170{ }^{\circ} \mathrm{C}$ and $8.0 \mathrm{MPa}$. The LHSV tained at around $0.5 \mathrm{~h}^{-1}$, according to the industrial production conditions $[4,32,33]$. The product amines collected at $\sim 30 \mathrm{~h}$ were used to assess the catalytic performance. The results of the amination reaction over the $\mathrm{Ni}-\mathrm{Re} / \mathrm{SiO}_{2}$ catalysts are shown in Table 3. Upon increasing the particle size from 4.5 to 18.0 $\mathrm{nm}$, the MEA conversion decreased from $85.7 \%$ to $51.1 \%$ and the selectivity to EDA showed a linear increase (from $51.5 \%$ to $65.6 \%$ ). Moreover, decreasing of the particle size significantly improved the selectivity to PIP, while also reducing the generation of the AEEA by-product. At the same time, the selectivities to DETA, HEP, and AEP showed a slight increase as the particle size of the $\mathrm{Ni}-\mathrm{Re} / \mathrm{SiO}_{2}$ catalysts decreased. The results show that the $\mathrm{Ni}-\mathrm{Re} / \mathrm{SiO}_{2}-4.5$ catalyst, with the lowest metal particle size, exhibited the highest yield (66.4\%) of the desired EDA and PIP amines. To the best of our knowledge, the value obtained in this work is higher than those reported in previous studies or patents. Zhang et al. [34] studied the amination of MEA on Co/H-ZSM-5 catalysts and obtained a total (EDA and PIP) yield of $42.5 \%$ at $230{ }^{\circ} \mathrm{C}$ and $6.0 \mathrm{MPa}$. Ding and coworkers [33] assessed the catalytic performance of $\mathrm{Ni}-\mathrm{Re} / \mathrm{Al}_{2} \mathrm{O}_{3}$ catalysts for MEA amination in a fixed bed reactor. The $\mathrm{Ni}-\mathrm{Re} / \mathrm{Al}_{2} \mathrm{O}_{3}$ catalyst showed a yield of $52.3 \%$ at $160{ }^{\circ} \mathrm{C}$ and $8.0 \mathrm{MPa}$. Chang et al. [32] described Ni-based catalysts for the MEA amination reaction. The highest total yield of EDA and PIP was reported to be $41.0 \%$ at $180{ }^{\circ} \mathrm{C}$ and $16.5 \mathrm{MPa}$. Another example is $\mathrm{Ni}-\mathrm{Re} / \mathrm{Al}_{2} \mathrm{O}_{3}$ that showed an EDA and PIP total yield of $57.8 \%$ for the amination of MEA at $180{ }^{\circ} \mathrm{C}$ and $12.5 \mathrm{MPa}$ [4]. According to the re- ports, the MEA amination reaction was always performed under high pressure (>12 MPa), because the formation of supercritical $\mathrm{NH}_{3}$ at a high reaction pressure was deemed crucial to improve the catalyst activity $[35,36]$. In conclusion, the $\mathrm{Ni}-\mathrm{Re} / \mathrm{SiO}_{2}-4.5$ catalyst, with the lowest particle size $(4.5 \mathrm{~nm})$, exhibited a higher yield of the desired EDA and PIP amines under a lower reaction pressure (8.0 MPa) compared to those of the catalyst systems previously used for MEA amination.

It should be noted that the activity of $\mathrm{Ni}-\mathrm{Re} / \mathrm{SiO}_{2}$ catalysts depends on the number of surface Ni sites [19,37]. The decrease of the Ni particle size improves the dispersion and number of surface $\mathrm{Ni}$ sites in $\mathrm{Ni}-\mathrm{Re} / \mathrm{SiO}_{2}$ catalysts. Therefore, the NO-pretreated $\mathrm{Ni}-\mathrm{Re} / \mathrm{SiO}_{2}-4.5$ catalyst, with the largest number of surface Ni sites (Table 2), exhibited the highest MEA conversion under the same reaction conditions (Table 3). As shown in Scheme 1, at the beginning there are two competitive reaction pathways for MEA amination: (1) the reaction of MEA with $\mathrm{NH}_{3}$ to form EDA, and (2) the self-amination reaction between two MEA molecules to form AEEA. Next, as the MEA conversion increases, the EDA and AEEA amines take part in the subsequent amination reactions to form other secondary or tertiary amines, including PIP, DETA, HEP, and AEP. The I:II:III molar ratio was used to measure the progress of the MEA amination reaction. As shown in Table 3, the I:II:III ratio decreased with an increase in MEA conversion, indicating that higher amounts of secondary (PIP and DETA) and tertiary (AEP and HEP) amines were generated. Furthermore, we calculated the ratio between primary (EDA) and secondary (AEEA, PIP, and DETA) amines (Pri.:Sec.), which is representative of the product distribution. As shown in Table 3, the Pri.:Sec. ratio increased with an increase in $\mathrm{Ni}$ particle size. However, it is unclear whether these differences were due to the reaction progress or to the Ni particle size. To investigate the effects of the Ni particle size on the amination activity and product distribution, the MEA conversion should be controlled at a low and similar level. The effects of the Ni particle size are discussed in the following section.

Table 3

MEA amination results of $\mathrm{Ni}-\mathrm{Re} / \mathrm{SiO}_{2}$ catalysts with different particle sizes.

\begin{tabular}{|c|c|c|c|c|c|c|c|c|c|}
\hline \multirow{3}{*}{ Catalyst } & \multirow{3}{*}{ Conversion (\%) } & \multicolumn{5}{|c|}{ Selectivity (\%) } & \multirow{3}{*}{ I:II:III b } & \multirow{3}{*}{ Pri.:Sec. ${ }^{c}$} & \multirow{3}{*}{$\begin{array}{l}\text { Yield of desired } \\
\text { amines }{ }^{\mathrm{d}}(\%)\end{array}$} \\
\hline & & \multicolumn{2}{|c|}{ I } & \multicolumn{2}{|c|}{ II } & \multirow{2}{*}{$\frac{\text { III }}{\text { Others }^{\mathrm{a}}}$} & & & \\
\hline & & EDA & AEEA & PIP & DETA & & & & \\
\hline $\mathrm{Ni}-\mathrm{Re} / \mathrm{SiO}_{2}-4.5$ & 85.7 & 51.5 & 7.4 & 26.0 & 9.7 & 5.5 & $59 / 36 / 5$ & 1.2 & 66.4 \\
\hline $\mathrm{Ni}-\mathrm{Re} / \mathrm{SiO}_{2}-10.5$ & 73.0 & 59.4 & 9.2 & 17.4 & 9.0 & 5.1 & $69 / 26 / 5$ & 1.7 & 56.0 \\
\hline $\mathrm{Ni}-\mathrm{Re} / \mathrm{SiO}_{2}-14.6$ & 57.6 & 64.1 & 12.1 & 12.0 & 7.6 & 4.2 & $76 / 20 / 4$ & 2.0 & 43.8 \\
\hline $\mathrm{Ni}-\mathrm{Re} / \mathrm{SiO}_{2}-18.0$ & 51.1 & 65.6 & 13.0 & 10.7 & 7.0 & 3.7 & $79 / 18 / 3$ & 2.1 & 38.9 \\
\hline
\end{tabular}

a HEP and AEP; ${ }^{\mathrm{b}}$ Ratio of different product amines: I $\left(n_{\mathrm{EDA}}+n_{\mathrm{AEEA}}\right) /$ II $\left(n_{\mathrm{PIP}}+n_{\mathrm{DETA}}\right) /$ III $\left(n_{\mathrm{HEP}}+n_{\mathrm{AEP}}\right)$; ${ }^{\mathrm{c}}$ Ratio between primary $(\mathrm{EDA})$ and secondary (AEEA, PIP, and DETA) amines; ${ }^{d}$ Yield of EDA and PIP. 

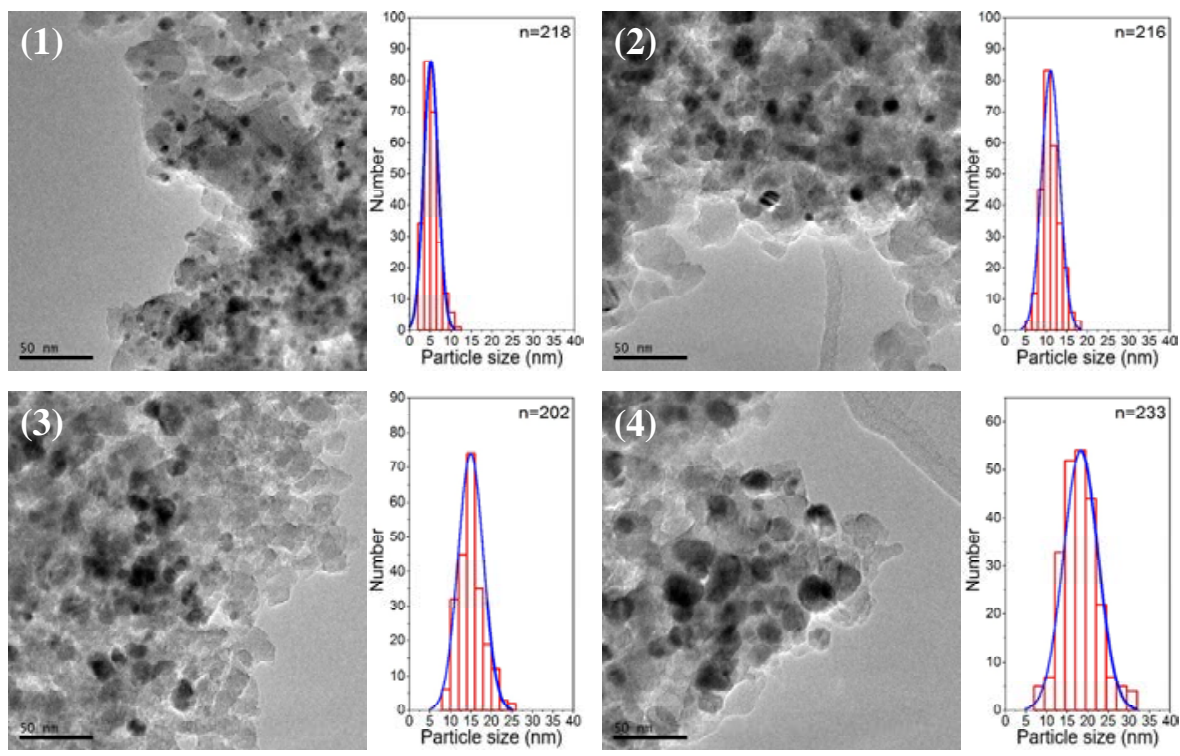

Fig. 5. TEM images and particle size distributions of spent catalysts. (1) Ni-Re/SiO $2-4.5$; (2) Ni-Re/SiO $2-10.5$; (3) $\mathrm{Ni}-\mathrm{Re} / \mathrm{SiO}_{2}-14.6$; (4) $\mathrm{Ni}-\mathrm{Re} / \mathrm{SiO}{ }_{2}-18.0$.

The morphology and particle size of the spent $\mathrm{Ni}-\mathrm{Re} / \mathrm{SiO}_{2}$ catalysts were also characterized by TEM. The TEM images and Ni particle size distributions are shown in Fig. 5 and Table 2. The comparison of the fresh and spent $\mathrm{Ni}-\mathrm{Re} / \mathrm{SiO}_{2}$ catalysts reveals that the $\mathrm{Ni}$ particle sizes showed very little changes after amination.

\subsection{Effects of Ni particle size on catalytic performance}

The intrinsic reaction rates and TOFs measured for the $\mathrm{Ni}-\mathrm{Re} / \mathrm{SiO}_{2}$ catalysts are shown in Table 4 . The I:II:III ratios for all catalysts were around 89/10/1, indicating that the amination reaction proceeded to a low and similar extent. The MEA amination results are listed in Table S1. The intrinsic reaction rate decreased by more than five times (from 83 to 15 $\mathrm{mmol} \cdot \mathrm{g}_{\text {cat }}{ }^{-1} \cdot \mathrm{h}^{-1}$ ) as the $\mathrm{Ni}$ particle size increased from 4.5 to $18.0 \mathrm{~nm}$. The TOF of MEA conversion of the $\mathrm{Ni}-\mathrm{Re} / \mathrm{SiO}_{2}$ catalysts showed a slight increase from 193 to $253 \mathrm{~h}^{-1}$ with the increase of the $\mathrm{Ni}$ particle size, indicating that the larger size of the $\mathrm{Ni}$ particles had a positive effect on the activity of the $\mathrm{Ni}-\mathrm{Re} / \mathrm{SiO}_{2}$ catalysts. Shimizu et al. [19] reported that the TOF of per surface Ni site increased with a decrease in $\mathrm{Ni}$ particle size. Such difference might be due to the different substrates and reaction pressure used. Turning to the product distribution, the Pri.:Sec. molar ratio increased linearly from 1.0 to 2.0 as the Ni particle size increased, demonstrating that the surface $\mathrm{Ni}$ sites in larger particles favored the formation of primary amines. Furthermore, the EDA:AEEA ratio was used to study the competitive reactions of carbonyl compounds (2-aminoacetaldehyde) with $\mathrm{NH}_{3}$ and another MEA molecule (Scheme 1). As shown in Table 4, the EDA:AEEA ratio increased from 1.3 to 2.7 when the Ni particle size increased from 4.5 to $18.0 \mathrm{~nm}$. As the selectivity to DETA of the four $\mathrm{Ni}-\mathrm{Re} / \mathrm{SiO}_{2}$ catalysts was almost equal (4.7\%-5.8\%), the increase in EDA cannot originate from the inhibition of the second amination reaction of EDA. The higher EDA:AEEA ratio indicates that the condensation between 2-aminoacetaldehyde and $\mathrm{NH}_{3}$ was facilitated, or that the condensation between 2-aminoacetaldehyde and MEA was inhibited during the first amination process (Scheme 1). To further analyze the size effects on the reaction pathway, the TOF values of EDA and AEEA formation on $\mathrm{Ni}-\mathrm{Re} / \mathrm{SiO}_{2}$ catalysts are also listed in Table 4. Upon increasing the size of the Ni particles, TOF EDA increased from 63 to $119 \mathrm{~h}^{-1}$, while TOF $_{\text {AEEA }}$ remained almost constant $\left(44-49 \mathrm{~h}^{-1}\right)$. These results indicate that the Ni particle size affected the competitive reactions during the amination reaction. The amination between MEA and $\mathrm{NH}_{3}$ molecules to form EDA was more favorable on larger $\mathrm{Ni}$ particles of the $\mathrm{Ni}-\mathrm{Re} / \mathrm{SiO}_{2}$ catalysts during the first amination process.

It is well known that the surface chemical properties and electronic structure vary with the metal particle size [38,39]. To understand the relationship between metal particle size and catalytic performance, the electronic state of the nanoparticles of $\mathrm{Ni}-\mathrm{Re} / \mathrm{SiO}_{2}$ catalysts was studied using $\mathrm{CO}$-adsorbed FT-IR

Table 4

Intrinsic reaction rates and TOF data of $\mathrm{Ni}-\mathrm{Re} / \mathrm{SiO}_{2}$ catalysts with different particle sizes. ${ }^{\mathrm{a}}$

\begin{tabular}{lcccrr}
\hline Catalyst & I:II:III & $\begin{array}{c}\text { Intrinsic reaction rate } \\
\left(\mathrm{mmol}_{\text {cat. }}{ }^{-1} \cdot \mathrm{h}^{-1}\right)\end{array}$ & Pri.:Sec. & EDA:AEEA & TOF \\
\hline $\mathrm{Ni}-\mathrm{Re} / \mathrm{SiO}_{2}-4.5$ & $88 / 11 / 1$ & 83 & 1.0 & 1.3 & 193 \\
$\mathrm{Ni}-\mathrm{Re} / \mathrm{SiO}_{2}-10.5$ & $87 / 11 / 2$ & 37 & 1.3 & 1.9 & 219 \\
$\mathrm{Ni}-\mathrm{Re} / \mathrm{SiO}_{2}-14.6$ & $91 / 08 / 1$ & 25 & 1.6 & 2.1 & 49 \\
$\mathrm{Ni}-\mathrm{Re} / \mathrm{SiO}_{2}-18.0$ & $89 / 10 / 1$ & 15 & 2.0 & 2.7 & 234 \\
\hline
\end{tabular}

a These values were determined at similar MEA conversion rates. The details are shown in the Experimental section. 


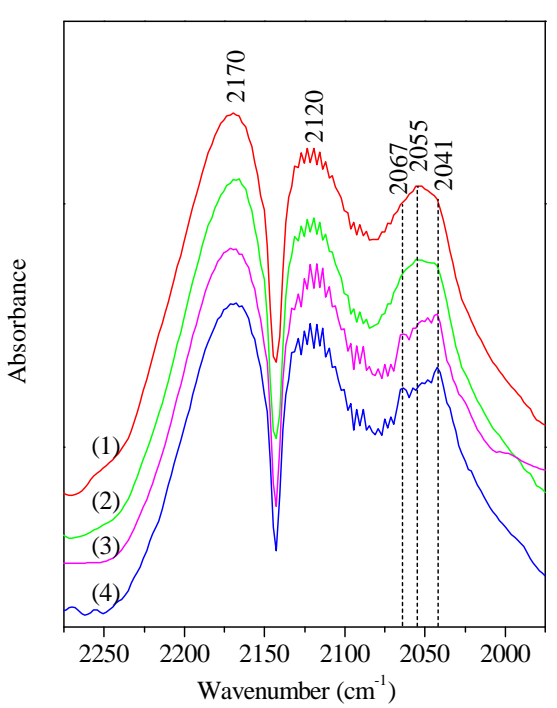

Fig. 6. FT-IR spectra of $\mathrm{CO}$ adsorption on reduced $\mathrm{Ni}-\mathrm{Re} / \mathrm{SiO}_{2}$ catalysts. (1) $\mathrm{Ni}-\mathrm{Re} / \mathrm{SiO}_{2}-4.5$; (2) $\mathrm{Ni}-\mathrm{Re} / \mathrm{SiO}_{2}-10.5$; (3) $\mathrm{Ni}-\mathrm{Re} / \mathrm{SiO}_{2}-14.6$; (4) $\mathrm{Ni}-\mathrm{Re} / \mathrm{SiO}_{2}-18.0$.

spectroscopy $[40,41]$. The FT-IR spectra are shown in Fig. 6. In general, all samples showed two absorption peaks centered at 2170 and $2120 \mathrm{~cm}^{-1}$, due to the physisorbed CO species on the $\mathrm{Ni}-\mathrm{Re} / \mathrm{SiO}_{2}$ catalysts $[42,43]$. The bands corresponding to linearly adsorbed CO on surface step/corner Ni sites with lower coordination numbers were observed at 2067 and $2055 \mathrm{~cm}^{-1}$. The band around $2041 \mathrm{~cm}^{-1}$ could be ascribed to linear $\mathrm{CO}$ adsorbed on high-coordinated terrace Ni sites [44-46]. As indicated by the CO-adsorbed FT-IR results, the relative intensity of the band at $2041 \mathrm{~cm}^{-1}$ gradually increased with an increase in metal particle size in the $\mathrm{Ni}-\mathrm{Re} / \mathrm{SiO}_{2}$ catalysts. The absorbance ratios of the peaks at 2041 and $2055 \mathrm{~cm}^{-1}$ are also listed in Table S2. These ratios increased with an increase in Ni particle size, indicating a greater proportion of surface Ni sites with high coordination number. The CO-probed IR results indicate that the electronic structure of the $\mathrm{Ni}-\mathrm{Re} / \mathrm{SiO}_{2}$ catalysts was influenced by the Ni particle size, which was probably the main reason for the difference in catalytic performance.

The $\mathrm{H}_{2}$-TPD method was used to further investigate the surface properties of $\mathrm{Ni}$ in the $\mathrm{Ni}-\mathrm{Re} / \mathrm{SiO}_{2}$ catalysts. The $\mathrm{H}_{2}$-TPD profiles and corresponding deconvoluted peaks are shown in Fig. 7. No $\mathrm{H}_{2}$ desorption on reduced $\mathrm{Re} / \mathrm{SiO}_{2}$ and unreduced $\mathrm{Ni}-\mathrm{Re} / \mathrm{SiO}_{2}$ catalysts was detected by TCD. Therefore, the $\mathrm{H}_{2}$ amount detected in the $\mathrm{Ni}-\mathrm{Re} / \mathrm{SiO}_{2}$ catalysts was ascribed to the hydrogen adsorbed on Ni sites. All samples showed a broad peak in the range of $50-480{ }^{\circ} \mathrm{C}$, which included several components. Four peaks around $94,170,238$, and $315^{\circ} \mathrm{C}$ were obtained after deconvolution. It has been reported that $\mathrm{Ni}$ atom at different sites (terraces, steps, and corners) show different hydrogen adsorption strength $[9,47,48]$. Hydrogen was weakly adsorbed on high-coordinated terrace $\mathrm{Ni}$. In contrast, corner $\mathrm{Ni}$ sites with low coordination number showed the highest hydrogen adsorption strength. According to a previous study, the peak at $94{ }^{\circ} \mathrm{C}$ was attributed to the desorption of weakly adsorbed $\mathrm{H}_{2}$. The three other peaks at higher temperature could

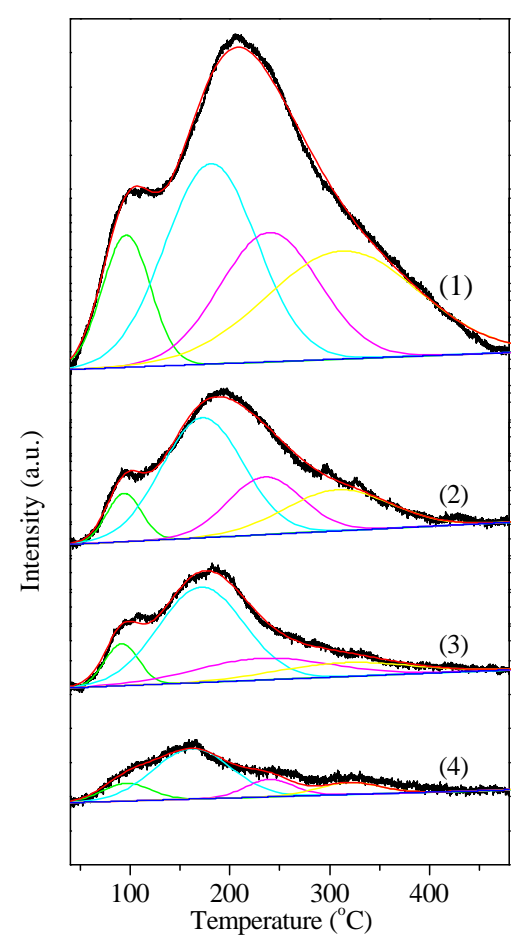

Fig. 7. $\mathrm{H}_{2}$-TPD profiles of $\mathrm{Ni}-\mathrm{Re} / \mathrm{SiO}_{2}$ catalysts. (1) $\mathrm{Ni}-\mathrm{Re} / \mathrm{SiO}_{2}-4.5$; (2) $\mathrm{Ni}-\mathrm{Re} / \mathrm{SiO}_{2}-10.5$; (3) Ni-Re/SiO $2-14.6$; (4) Ni-Re/SiO $2-18.0$.

be assigned to desorption of hydrogen from $\mathrm{Ni}$ at terrace, step, and corner sites, respectively. The calculated proportions of different Ni surface sites are shown in Fig. 8. The proportion of terrace $\mathrm{Ni}$ sites increased linearly with the particle size, while the proportion of step/corner Ni showed the opposite trend. The $\mathrm{H}_{2}$-TPD results further confirm that the proportion of different surface Ni sites varied with the particle size of the $\mathrm{Ni}-\mathrm{Re} / \mathrm{SiO}_{2}$ catalysts.

XPS was used to analyze the electronic structure of the $\mathrm{Ni}-\mathrm{Re} / \mathrm{SiO}_{2}$ catalysts. The of $\mathrm{Ni} 2 p$ XPS spectra the ex situ reduced $\mathrm{Ni}-\mathrm{Re} / \mathrm{SiO}_{2}$ catalysts and the deconvoluted peaks are

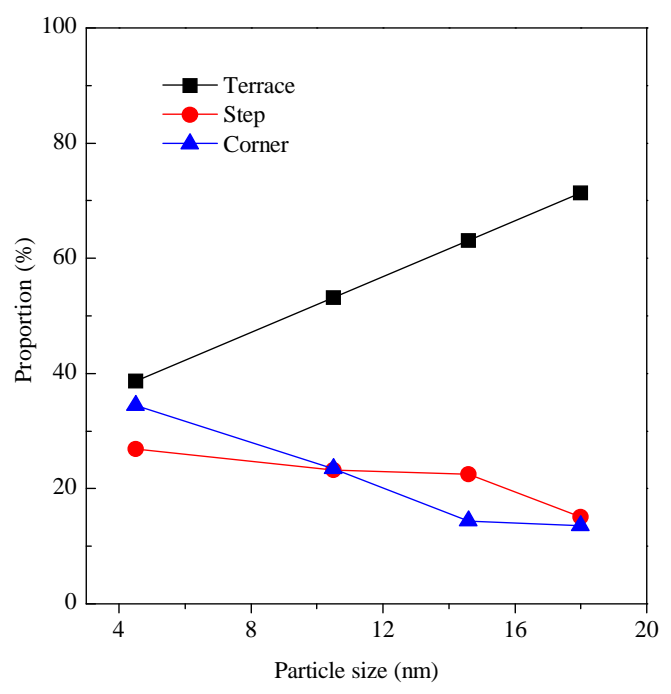

Fig. 8. Proportion of different surface Ni sites obtained from the $\mathrm{H}_{2}$-TPD results. 


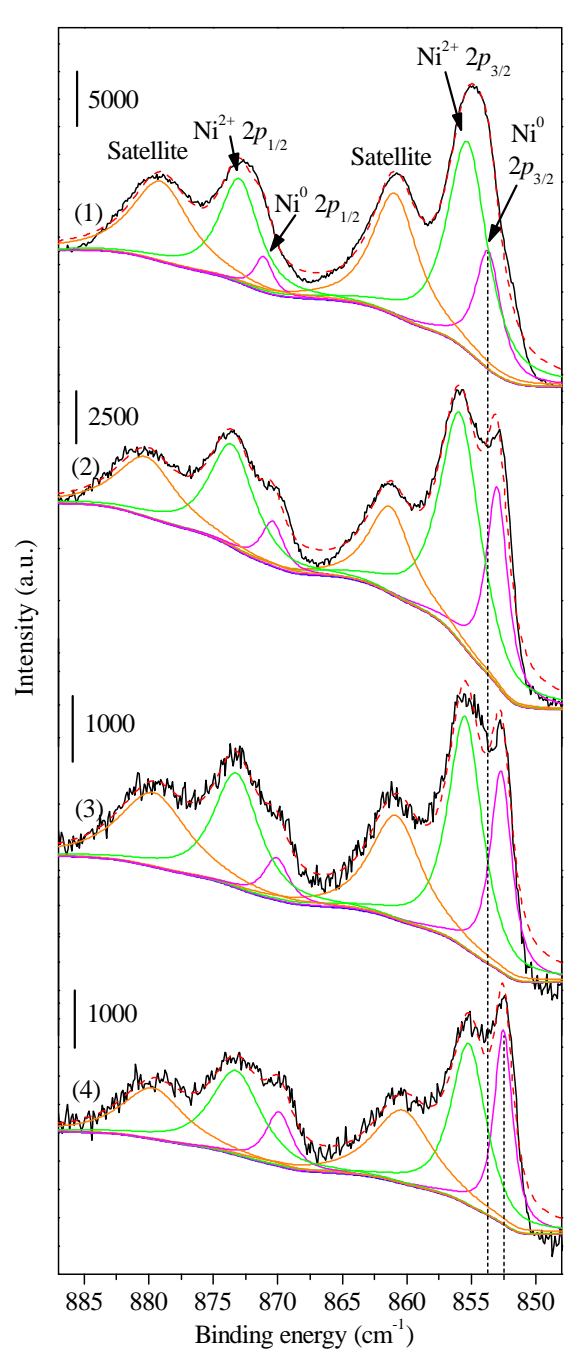

Fig. 9. $\mathrm{Ni} 2 p$ XPS spectra of $\mathrm{Ni}-\mathrm{Re} / \mathrm{SiO}_{2}-4.5$ (1); $\mathrm{Ni}-\mathrm{Re} / \mathrm{SiO}_{2}-10.5$ (2); $\mathrm{Ni}-\mathrm{Re} / \mathrm{SiO}_{2}-14.6$ (3); and $\mathrm{Ni}-\mathrm{Re} / \mathrm{SiO}_{2}-18.0$ (4).

Table 5

Binding energies and atomic ratios of $\mathrm{Ni}-\mathrm{Re} / \mathrm{SiO}_{2}$ catalysts.

\begin{tabular}{|c|c|c|c|c|}
\hline \multirow{2}{*}{ Catalyst } & \multicolumn{2}{|c|}{$\mathrm{Ni} 2 p_{3 / 2}(\mathrm{eV})$} & \multirow{2}{*}{$\begin{array}{l}\mathrm{Ni}: S i \text { atomic } \\
\text { ratio }\end{array}$} & \multirow{2}{*}{$\begin{array}{c}\text { Ni reduction } \\
\text { degree }(\%)\end{array}$} \\
\hline & $\mathrm{Ni}^{2+}$ & $\mathrm{Ni}^{0}$ & & \\
\hline $\mathrm{Ni}-\mathrm{Re} / \mathrm{SiO}_{2}-4.5$ & 855.5 & 853.7 & 0.087 & 27 \\
\hline $\mathrm{Ni}-\mathrm{Re} / \mathrm{SiO}_{2}-10.5$ & 855.4 & 853.0 & 0.049 & 32 \\
\hline $\mathrm{Ni}-\mathrm{Re} / \mathrm{SiO}_{2}-14.6$ & 855.3 & 852.7 & 0.013 & 36 \\
\hline $\mathrm{Ni}-\mathrm{Re} / \mathrm{SiO}_{2}-18.0$ & 855.2 & 852.5 & 0.011 & 39 \\
\hline
\end{tabular}

shown in Fig. 9, while the curve-fitting data are listed in Table 5. The peaks around 860 and $879 \mathrm{eV}$ were ascribed to the shake-up satellite peaks of $\mathrm{Ni}^{2+} 2 p_{3 / 2}$ and $\mathrm{Ni}^{2+} 2 p_{1 / 2}$, respectively $[21,49]$. It can be observed that the $\mathrm{Ni}^{0} 2 p_{3 / 2}$ peak shifts from 853.7 to $852.5 \mathrm{eV}$ with an increase in size of Ni particles, probably due to the different atomic relaxation in large and small nanoparticles [50,51]. The surface Ni sites showed a lower electron density in small than large particles. Furthermore, oxidation of the catalysts took place during their preparation, and varying degrees of oxidation were observed in the four catalysts. The decrease in particle size led to a significantly higher proportion of $\mathrm{Ni}^{2+}$ (around $855 \mathrm{eV}$ ), indicating that small $\mathrm{Ni}$ particles were more easily oxidized. The Ni:Si atomic ratio decreased from 0.087 to 0.011 upon increasing the Ni particle size, which was ascribed to the lower Ni dispersion. In conclusion, the XPS results indicate that the electronic properties of surface Ni sites were influenced by the particle size. The electron density of Ni increased with an increase in particle size.

\subsection{Discussion}

Few previous reports investigated the effects of the metal particle size on the amination of alcohol amines. In this study, to focus on the effects of the Ni particle size, we employed inert silica to eliminate support interferences. As shown in Fig. S1, the activity of monometallic $\mathrm{Ni} / \mathrm{SiO}_{2}$ decreased rapidly in the initial reaction stage. According to previous studies, the deactivation of $\mathrm{Ni} / \mathrm{SiO}_{2}$ catalysts is due to the sintering of metallic $\mathrm{Ni}$ particles under $\mathrm{H}_{2}$ and $\mathrm{NH}_{3}$ atmospheres at high pressure $[21,52,53]$. Therefore, the Re promoter was introduced in the $\mathrm{Ni} / \mathrm{SiO}_{2}$ catalyst system in order to maintain the stability of the Ni particle size. To assimilate the effect of Re, the metal loading of $\mathrm{Re}$ in all $\mathrm{Ni}-\mathrm{Re} / \mathrm{SiO}_{2}$ catalysts was kept constant at $1.5 \mathrm{wt} \%$ (Table 2). By adjusting the calcination atmosphere and reduction temperature, $\mathrm{Ni}-\mathrm{Re} / \mathrm{SiO}_{2}$ catalysts with varying $\mathrm{Ni}$ particle sizes (4.5-18.0 nm, Table 2) were synthesized. The monometallic $\mathrm{Re} / \mathrm{SiO}_{2}$ catalyst showed no activity in MEA amination. In addition, the XRD and high-resolution TEM results reveal that the structure of Ni was not modified by Re. After amination, the Ni particle sizes in spent $\mathrm{Ni}-\mathrm{Re} / \mathrm{SiO}_{2}$ catalysts (Table 2) showed very little changes compared to the fresh catalysts.

The catalytic performances of the $\mathrm{Ni}-\mathrm{Re} / \mathrm{SiO}_{2}$ catalysts (Table 3) reveal that the MEA conversion and yield of desired amines (EDA and PIP) increased with a decrease in Ni particle size. The $\mathrm{Ni}-\mathrm{Re} / \mathrm{SiO}_{2}-4.5$ catalyst showed the highest yield (66.4\%). To the best of our knowledge, this is the highest MEA amination yield reported to date. As the MEA amination reaction is catalyzed by metallic Ni sites, the main reason for the high MEA conversion is the increased surface $\mathrm{Ni}$ area of the $\mathrm{Ni}-\mathrm{Re} / \mathrm{SiO}_{2}-4.5$ catalyst.

The structure-activity relationship between $\mathrm{Ni}$ particle size and MEA amination was then investigated. The experimental results (Table 4) indicate that the TOF ${ }_{\mathrm{MEA}}$ and molar ratio of primary to secondary amines increased with an increase in $\mathrm{Ni}$ particle size of the $\mathrm{Ni}-\mathrm{Re} / \mathrm{SiO}_{2}$ catalysts. Based on the above results, we conclude that increasing the size of Ni particles of $\mathrm{Ni}-\mathrm{Re} / \mathrm{SiO}_{2}$ catalysts not only has a positive effect on their activity for MEA amination, but also improves their selectivity to primary amines. Further analysis reveals that the TOFEDA increased from $63 \mathrm{~h}^{-1}$ for $\mathrm{Ni}-\mathrm{Re} / \mathrm{SiO}_{2}-4.5$ to $119 \mathrm{~h}^{-1}$ for $\mathrm{Ni}-\mathrm{Re} / \mathrm{SiO}_{2}-18.0$. On the other hand, the Ni particle size had

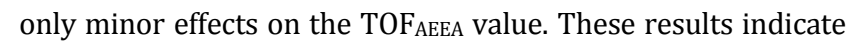
that the Ni particle size affected the reaction pathway of the amination reaction (Scheme 1). More specifically, increasing the metal particle size could promote the amination reaction between MEA and $\mathrm{NH}_{3}$ molecules over $\mathrm{Ni}-\mathrm{Re} / \mathrm{SiO}_{2}$ catalysts. This phenomenon could be attributed to the changes in surface electronic structure of the metal particles, as shown by CO-adsorbed FT-IR, $\mathrm{H}_{2}$-TPD, and XPS measurements. The change in electronic properties may have an impact on the ad- 
sorption and/or dehydrogenation progress of MEA during amination, leading to a different product distribution. Taking $\mathrm{Ni}-\mathrm{Re} / \mathrm{SiO}_{2}-4.5$ and $\mathrm{Ni}-\mathrm{Re} / \mathrm{SiO}_{2}-18.0$ catalysts as an examples, the adsorption strength of MEA would be lower on the $\mathrm{Ni}-\mathrm{Re} / \mathrm{SiO} 2-18.0$ than $\mathrm{Ni}-\mathrm{Re} / \mathrm{SiO}_{2}-4.5$ catalyst, due to the difference in the electron density and the coordinatively unsaturated environment of surface $\mathrm{Ni}$ atoms. After dehydrogenation of MEA, the carbonyl compounds would be more easily desorbed from the high-coordinated terrace $\mathrm{Ni}$ sites and transferred to the liquid phase to react with $\mathrm{NH}_{3}$ (Scheme 3), compared to the same process on surface step/corner Ni sites. For these reasons, the $\mathrm{Ni}-\mathrm{Re} / \mathrm{SiO}_{2}-18.0$ catalyst with a higher proportion of terrace $\mathrm{Ni}$ sites was more active in the formation of EDA.

To prove this hypothesis, we tested the adsorption strength of MEA on $\mathrm{Ni}-\mathrm{Re} / \mathrm{SiO}_{2}-4.5$ and $\mathrm{Ni}-\mathrm{Re} / \mathrm{SiO}_{2}-18.0$ catalysts using in situ FT-IR measurements. The adsorption of MEA on $\mathrm{Ni}-\mathrm{Re} / \mathrm{SiO}_{2}$ took place at $50{ }^{\circ} \mathrm{C}$ and physically adsorbed MEA was desorbed in vacuum at about 40-50 Pa. Next, the changes in the MEA-adsorbed IR spectra were recorded during a tem- perature programmed process in vacuum. The FT-IR spectra are shown in Fig. 10. For comparison, we also recorded the IR spectra of liquid and vapor MEA, shown in Fig. S2. Liquid MEA showed three peaks at 1599, 1460, and $1358 \mathrm{~cm}^{-1}$, which were assigned to the deformation vibration of $\mathrm{NH},-\mathrm{CH}_{2}$, and $\mathrm{OH}$ groups, respectively [54]. An adsorption peak at $1625 \mathrm{~cm}^{-1}$ was detected in the spectrum of MEA vapor. Combined with the characteristic peaks of the $\mathrm{CH}$ stretching vibration at 2931 and $2864 \mathrm{~cm}^{-1}$ and the $\mathrm{NH}$ stretching vibration at $3334 \mathrm{~cm}^{-1}$, the peak at $1625 \mathrm{~cm}^{-1}$ was assigned to the deformation vibration of $\mathrm{NH}$, which was blue-shifted compared to that in the spectrum of liquid MEA. In the case of MEA vapor adsorbed on $\mathrm{Ni}-\mathrm{Re} / \mathrm{SiO}_{2}$ catalysts (Fig. 10), $\mathrm{NH}$ deformation bands were observed around $1630 \mathrm{~cm}^{-1}$. The peak intensity decreased gradually with an increase in temperature, indicating that MEA was desorbed from the surface of the $\mathrm{Ni}-\mathrm{Re} / \mathrm{SiO}_{2}$ catalysts. The peak intensity of the $\mathrm{Ni}-\mathrm{Re} / \mathrm{SiO}_{2}-4.5$ catalyst (Fig. 10(a)) was nearly level with the baseline when the temperature reached approximately $100{ }^{\circ} \mathrm{C}$, indicating that MEA was almost completely desorbed from surface of catalyst. However, in Fig.
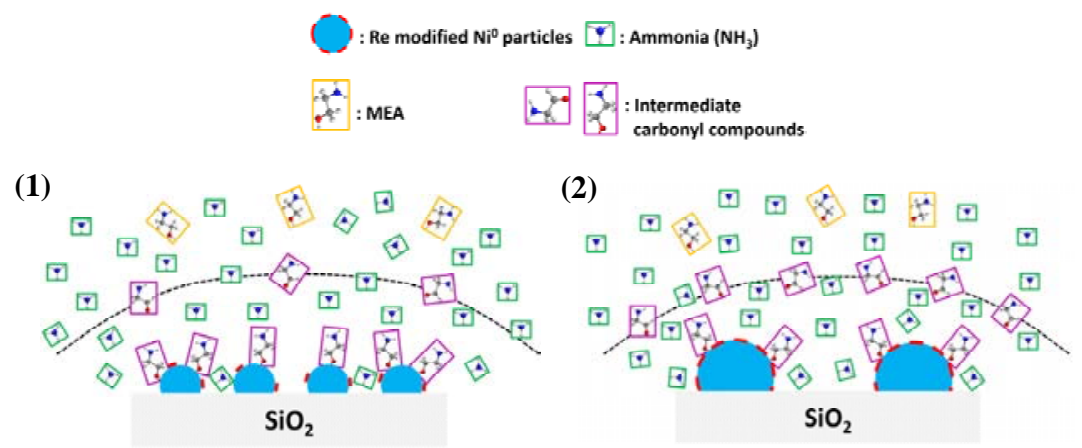

Scheme 3. Schematic representation of the desorption and diffusion of MEA on the surface of (1) small and (2) large metal particles in Ni-Re/SiO 2 catalysts during MEA amination.
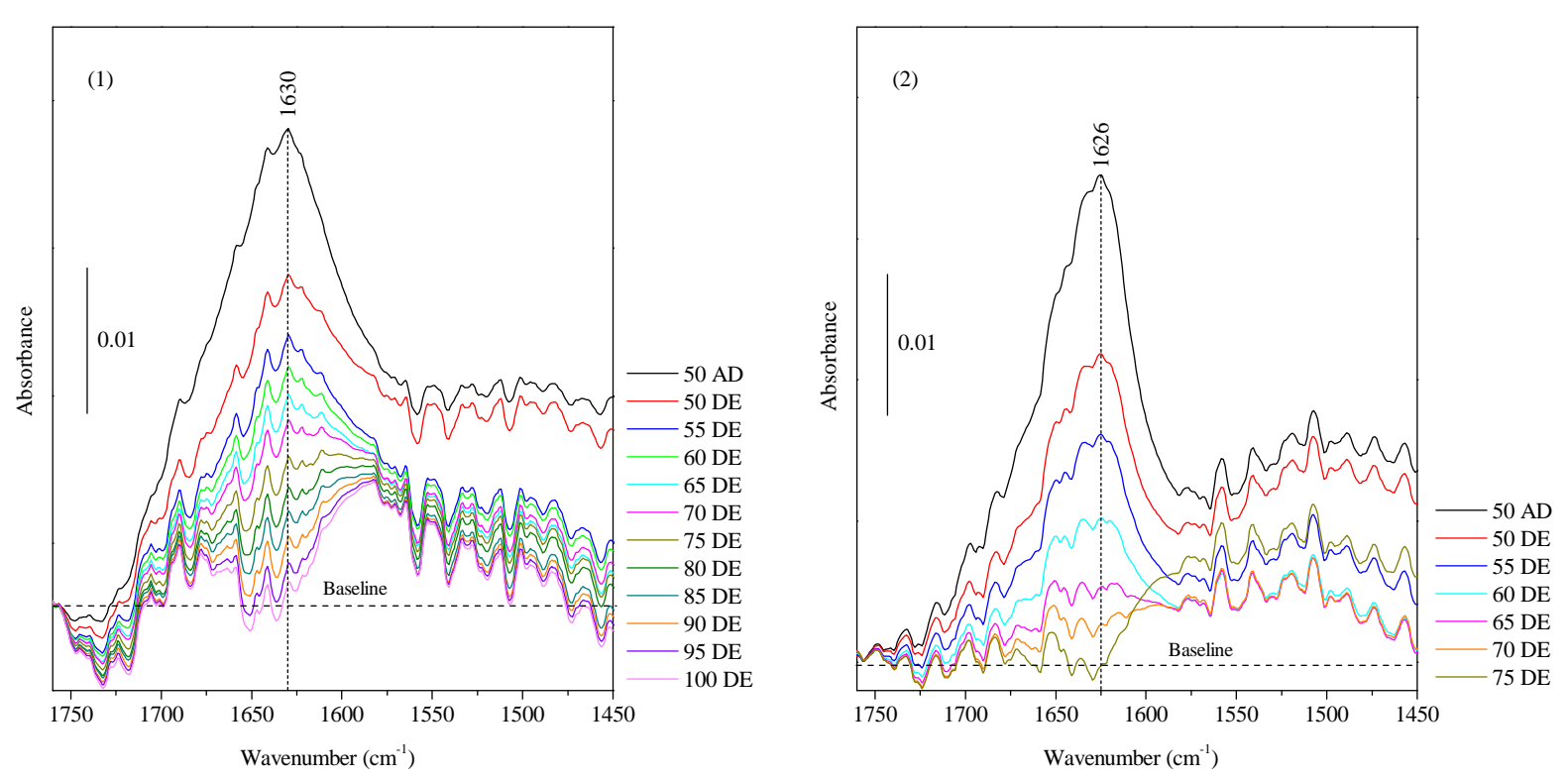

Fig. 10. FT-IR spectra of adsorbed MEA on $\mathrm{Ni}-\mathrm{Re} / \mathrm{SiO}_{2}-4.5$ (1) and $\mathrm{Ni}-\mathrm{Re} / \mathrm{SiO}_{2}-18.0$ catalysts (2). 
10(2), the peak disappeared at a lower temperature (70-75 ${ }^{\circ} \mathrm{C}$ ), demonstrating that MEA desorbed more easily from the $\mathrm{Ni}-\mathrm{Re} / \mathrm{SiO}_{2}-18.0$ catalyst. The MEA-adsorbed FT-IR results prove that the adsorption strength of MEA was weaker on the $\mathrm{Ni}-\mathrm{Re} / \mathrm{SiO}_{2}-18.0$ than $\mathrm{Ni}-\mathrm{Re} / \mathrm{SiO}_{2}-4.5$ catalyst.

In conclusion, increasing the $\mathrm{Ni}$ particle size in $\mathrm{Ni}-\mathrm{Re} / \mathrm{SiO}_{2}$ catalysts slightly improved the TOF of MEA amination, and enhanced the selectivity to EDA. Further analyses indicate that increasing the Ni particle size affected the reaction pathway by promoting the amination between MEA and $\mathrm{NH}_{3}$ to form EDA. In practical applications, the decrease in Ni particle size could improve the utilization of $\mathrm{Ni}$ species by enhancing the metal dispersion of the $\mathrm{Ni}-\mathrm{Re} / \mathrm{SiO}_{2}$ catalysts. Although the decrease in Ni particle size partly reduced the TOF ${ }_{M E A}$, it could improve the yield of desired amines. In our study, the $\mathrm{Ni}-\mathrm{Re} / \mathrm{SiO}_{2}-4.5$ catalyst with Ni particle sizes of $4.5 \mathrm{~nm}$ exhibited the highest yield of EDA and PIP amines.

\section{Conclusions}

In this study, we provided insights into the effects of the $\mathrm{Ni}$ particle size of $\mathrm{Ni}-\mathrm{Re} / \mathrm{SiO}_{2}$ catalysts on MEA amination. $\mathrm{Ni}-\mathrm{Re} / \mathrm{SiO}_{2}$ catalysts (Ni $20 \mathrm{wt} \%$, Re $1.5 \mathrm{wt} \%$ ) with variable $\mathrm{Ni}$ particle sizes were prepared by adjusting the calcination atmosphere and reduction temperature. The Ni particle sizes of the $\mathrm{Ni}-\mathrm{Re} / \mathrm{SiO}_{2}$ catalysts remained almost unchanged after the amination reaction. The $\mathrm{Ni}-\mathrm{Re} / \mathrm{SiO}_{2}-4.5$ catalyst, with an average particle size of $4.5 \mathrm{~nm}$, showed the highest yield (66.4\%) of the desired amines (EDA and PIP), which was higher than the yields reported in previous studies and patents. The high MEA conversion of the $\mathrm{Ni}-\mathrm{Re} / \mathrm{SiO}_{2}-4.5$ catalyst was due to its high $\mathrm{Ni}$ dispersion and abundant surface Ni sites.
The amination of MEA was a structure-sensitive reaction. The variation of the Ni particle size affected the activity of the $\mathrm{Ni}-\mathrm{Re} / \mathrm{SiO}_{2}$ catalysts and their product distribution during the reaction. The experimental results indicate that the TOF values of MEA amination were higher for larger Ni particles. For the amination products, the TOFEDA and Pri.:Sec. values increased with an increase in Ni particle size. Further analyses show that the Ni particle size influenced the electron density and coordination environment of surface $\mathrm{Ni}$ sites in $\mathrm{Ni}-\mathrm{Re} / \mathrm{SiO}_{2}$ catalysts. Increasing the $\mathrm{Ni}$ particle size enhanced the proportion of terrace $\mathrm{Ni}$ sites and increased the electron density of surface $\mathrm{Ni}$ sites. Large Ni particles were more beneficial for the desorption of intermediate products, thus facilitating the amination between MEA and $\mathrm{NH}_{3}$ to form EDA.

\section{References}

[1] G. F. Mackenzie, US Patent 2861995, 1958.

[2] R. Lichtenberger, F. Weiss, US Patent 3068290, 1962.

[3] P. H. Moss, N. B. Godfrey, US Patent 3037023, 1962.

[4] S. W. King, US Patent 5750790, 1998.

[5] A. Baiker, J. Kijenski, Catal. Rev. Sci. Eng., 1985, 27, 653-697.

[6] H. Kimura, Catal. Rev. Sci. Eng., 2011, 53, 1-90.

[7] K. Shimizu, Catal. Sci. Technol., 2015, 5, 1412-1427.

[8] Q. X. Li, G. Y. Zhang, S. Y. Peng, Chin. J. Catal., 2001, 22, 7-10.

[9] F. Yang, D. Liu, Y. Zhao, H. Wang, J. Han, Q. Ge, X. Zhu, ACS Catal., 2018, 8, 1672-1682.

[10] L. Liu, A. Corma, Chem. Rev., 2018, 118, 4981-5079.

[11] Q. Zhang, W. Deng, Y. Wang, Chem. Commun., 2011, 47, 9275-9292.

[12] D. Baudouin, U. Rodemerck, F. Krumeich, A. D. Mallmann, K. C. Szeto, H. Ménard, L. Veyre, J. P. Candy, P. B. Webb, C. Thieuleux, C. Coperet, J. Catal., 2013, 297, 27-34.

\section{Graphical Abstract}

Chin. J. Catal., 2019, 40: 567-579 doi: S1872-2067(19)63302-4

Effects of Ni particle size on amination of monoethanolamine over $\mathrm{Ni}-\mathrm{Re} / \mathrm{SiO}_{2}$ catalysts

Lei Ma, Li Yan*, An-Hui Lu, Yunjie Ding *

Dalian Institute of Chemical Physics, Chinese Academy of Sciences; Dalian University of Technology;

University of Chinese Academy of Sciences
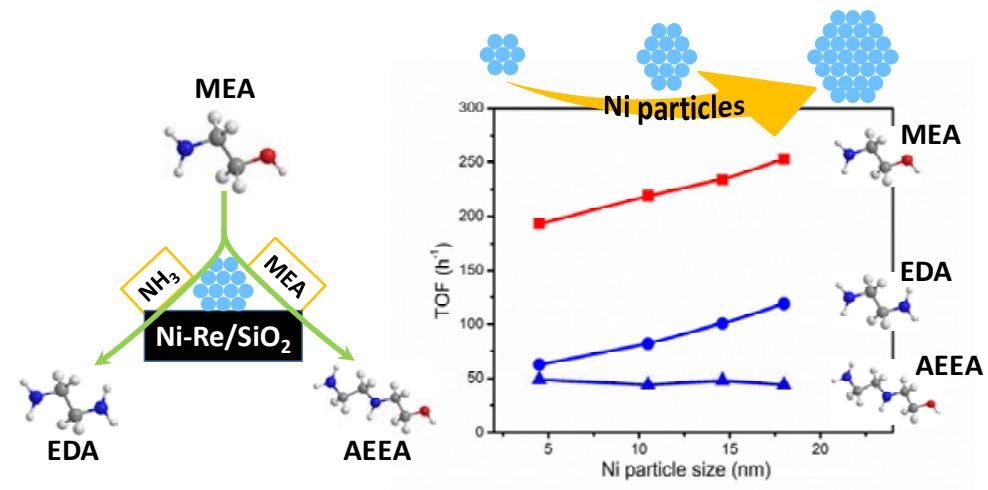

The reaction pathway of MEA amination by $\mathrm{Ni}-\mathrm{Re} / \mathrm{SiO}_{2}$ catalyst is affected by the Ni particle size. Larger Ni particles are more beneficial for the amination of MEA and $\mathrm{NH}_{3}$ to form EDA. 
[13] J. Z. Guo, Z. Y. Hou, J. Gao, X. M. Zheng, Chin. J. Catal., 2007, 28, 22-26.

[14] S. Y. Wang, B. Zeng, C. Li, Chin. J. Catal., 2018, 39, 1219-1227.

[15] Y. X. Chen, Z. W. Huang, G. Xiao, M. Zhen, J. M. Chen, X. F. Tang, Chin. J. Catal., 2017, 38, 1588-1596.

[16] Z. Chen, Y. Liang, D. S. Jia, Z. M. Cui, W. G. Song, Chin. J. Catal., 2017, 38, 651-657.

[17] R. J. Shi, F. Wang, X. L. Mu, N. Ta, Y. Li, X. M. Huang, W. J. Shen, Chin. J. Catal., 2010, 31, 626-630.

[18] P. M. Mortensen, J. D. Grunwaldt, P. A. Jensen, A. D. Jensen, Catal. Today, 2016, 259, 277-284.

[19] K. I. Shimizu, N. Imaiida, K. Kon, S. M. A. H. Siddiki, A. Satsuma, ACS Catal., 2013, 3, 998-1005.

[20] R. C. Reuel, C. H. Bartholomew, J. Catal., 1984, 85, 63-77.

[21] L. Ma, L. Yan, A. H. Lu, Y. J. Ding, RSC Adv., 2018, 8, 8152-8163.

[22] L. Ma, K. C. Sun, M. Luo, L. Yan, Z. Jiang, A. H. Lu, Y. J. Ding, J. Phys. Chem. C, 2018, 122, 23011-23025.

[23] S. R. Bare, S. D. Kelly, F. D. Vila, E. Boldingh, E. Karapetrova, J. Kas, G. E. Mickelson, F. S. Modica, N. Yang, J. J. Rehr, J. Phys. Chem. C, 2011, 115, 5740-5755.

[24] C. Louis, Z. X. Cheng, M. Che, J. Phys. Chem., 1993, 97, 5703-5712.

[25] X. Kong, Y. Zhu, H. Zheng, X. Li, Y. Zhu, Y. W. Li, ACS Catal., 2015, 5, 5914-5920.

[26] B. Mile, D. Stirling, M. A. Zammitt, A. Lovell, M. Webb, J. Catal., 1988, 114, 217-229.

[27] X. F. Wang, J. X. Chen, Chin. J. Catal., 2017, 38, 1818-1830.

[28] J. R. A. Sietsma, J. D. Meeldijk, M. Versluijs-Helder, A. Broersma, A. J. Van Dillen, P. E. de Jongh, K. P. de Jong, Chem. Mater., 2008, 20, 2921-2931.

[29] J. R. A. Sietsma, H. Friedrich, A. Broersma, M. Versluijs-Helder, A. J. Van Dillen, P. E. de Jongh, K. P. de Jong, J. Catal., 2008, 260, 227-235.

[30] J. R. A. Sietsma, J. D. Meeldijk, J. P. den Breejen, M. Versluijs-Helder, A. J. Van Dillen, P. E. de Jongh, K. P. de Jong, Angew. Chem. Int. Ed., 2007, 46, 4547-4549.

[31] S. L. Soled, E. Iglesia, R. A. Fiato, J. E. Baumgartner, H. Vroman, S. Miseo, Top. Catal., 2003, 26, 101-109.

[32] D. Chang, F. A. Sherrod, US Patent 5817593, 1998.

[33] L. Yan, Y. J. Ding, Y. Lv, X. B. Cheng, L. X. Ma, WO Patent
2013152548 A1, 2013

[34] Y. Zhang, G. Bai, X. Yan, Y. Li, T. Zeng, J. Wang, H. Wang, J. Xing, D. Luan, X. Tang, L. Chen, Catal. Commun., 2007, 8, 1102-1106.

[35] A. Fischer, T. Mallat, A. Baiker, Angew. Chem. Int. Ed., 1999, 38, 351-354.

[36] G. Jenzer, T. Mallat, A. Baiker, Catal. Lett., 1999, 61, 111-114.

[37] J. H. Cho, J. H. Park, T. S. Chang, J. E. Kim, C. H. Shin, Catal. Lett., 2013, 143, 1319-1327.

[38] J. M. Mayne, K. A. Dahlberg, T. A. Westrich, A. R. Tadd, J. W. Schwank, Appl. Catal. A, 2011, 400, 203-214.

[39] Y. Yao, Z. Yan, L. Chen, Z. Zhou, L. Liu, D. W. Goodman, Catal. Lett., 2012, 142, 1437-1444.

[40] C. Asokan, L. Derita, P. Christopher, Chin. J. Catal., 2017, 38, 1473-1480.

[41] H. J. Shen, X. Y. Wu, D. H. Jiang, X. N. Li, J. Ni, Chin. J. Catal., 2017, 38, 1597-1602.

[42] Y. K. Lee, S. T. Oyama, J. Catal., 2006, 239, 376-389.

[43] H. X. Cao, J. Zhang, C. L. Guo, J. G. Chen, X. K. Ren, Chin. J. Catal., 2017, 38, 1127-1137.

[44] C. Hu, Y. Chen, P. Li, H. Min, Y. Chen, A. Tian, J. Mol. Catal. A, 1996, 110, 163-169.

[45] G. Poncelet, M. A. Centeno, R. Molina, Appl. Catal. A, 2005, 288, 232-242.

[46] M. B. Jensen, S. Morandi, F. Prinetto, A. O. Sjåstad, U. Olsbye, G. Ghiotti, Catal. Today, 2012, 197, 38-49.

[47] A. S. Mårtensson, C. Nyberg, S. Andersson, Surf. Sci., 1988, 205, 12-24.

[48] B. Liu, M. T. Lusk, J. F. Ely, J. Phys. Chem. C, 2009, 113, 13715-13722.

[49] C. P. Li, A. Proctor, D. M. Hercules, Appl. Spectrosc., 1984, 38, 880-886.

[50] G. F. Liang, Y. Zhou, J. P. Zhao, A. Y. Khodakov, V. V. Ordomsky, ACS Catal., 2018, 8, 11226-11234.

[51] Z. J. Zhao, F. Liu, L. M. Qiu, L. Z. Zhao, S. K. Yan, Acta Phys.-Chim. Sin., 2008, 24, 1685-1688.

[52] J. Lif, M. Skoglundh, L. Löwendahl, Appl. Catal. A, 2002, 228,145-154.

[53] J. Lif, M. Skoglundh, L. Löwendahl, Appl. Catal. A, 2004, 274, 61-69.

[54] K. Segawa, S. Mizuno, Y. Maruyama, S. Nakata, Stud. Surf. Sci. Catal., 1994, 84, 1943-1950.

\title{
$\mathrm{Ni}-\mathrm{Re} / \mathrm{SiO}_{2}$ 催化剂中Ni颗粒尺寸对乙醇胺催化胺化反应的影响
}

\author{
马 雷 ${ }^{\mathrm{a}, \mathrm{b}, \mathrm{d}}$, 严 丽 $^{\mathrm{a}, \# \text {, 陆安慧 }}{ }^{\mathrm{b}}, 丁$ 云杰, ${ }^{\mathrm{a}, \mathrm{c}, *}$ \\ a中国科学院大连化学物理研究所, 洁净能源国家实验室(筹), 辽宁大连116023 \\ ${ }^{b}$ 大连理工大学化工学院, 精细化工国家重点实验室, 辽宁大连 116024 \\ c中国科学院大连化学物理研究所, 催化基础国家重点实验室, 辽宁大连 116023 \\ d中国科学院大学, 北京100049
}

摘要: 以醇和氨/胺为原料采用催化胺化法合成有机胺长期以来广受关注, 该工艺反应副产物只有水, 符合现代绿色化工理 念. 作为工业应用的成功案例, 乙醇胺(MEA)催化胺化法目前已成为生产乙撑胺(包括乙二胺(EDA), 哌嗪(PIP)等)的主要工 艺. MEA催化胺化通常在过渡金属催化剂上进行, 如 $\mathrm{Ni}$ 基催化剂, 反应过程遵循“借氢机理”, 经历了“脱氢-缩合胺化-加氢” 三个过程.

目前, 关于MEA胺化催化剂的研究主要以专利为主, 据我们所知, 对于催化剂金属颗粒尺寸和胺化性能之间的构效关 系的研究极少, 特别是对于金属粒径对胺化产物分布的影响, 目前还未见报道. 因此, 本文的目的是合成具有不同Ni颗粒 尺寸的 $\mathrm{Ni}-\mathrm{Re} / \mathrm{SiO}_{2}$ 催化剂, 通过滴流床反应器评价, 研究颗粒尺寸对MEA胺化活性和产物分布的影响. 采用控制催化剂焙 烧和还原条件的方法, 制备了四种不同 $\mathrm{Ni}$ 粒径的 $\mathrm{Ni}-\mathrm{Re} / \mathrm{SiO}_{2}$ 催化剂; 随后采用 $\mathrm{N}_{2}$ 物理吸附, $\mathrm{H}_{2}$ 程序升温还原, $\mathrm{X}$ 射线衍射, $\mathrm{H}_{2}$ 
化学吸附, 光电子能谱, 红外吸收光谱等对催化剂的孔结构、还原性、粒径分布、金属Ni活性比表面、分散度、表面Ni位 点类型和电子性质进行研究. MEA催化胺化反应在滴流床反应器上进行, 反应条件为 $170{ }^{\circ} \mathrm{C}, 8.0 \mathrm{MPa}, \mathrm{MEA}$ 液时空速 0.5 $\mathrm{h}^{-1}, \mathrm{NH}_{3}: \mathrm{MEA}$ 摩尔比10:1, $\mathrm{H}_{2}$ 含量2.5 mol\%.

表征结果证明, 成功制备了具有不同 $\mathrm{Ni}$ 粒径, 且尺寸分布集中的 $\mathrm{Ni}-\mathrm{Re} / \mathrm{SiO}_{2}$ 催化剂, Ni粒径分别为4.5, 10.5, 14.6, 18.0 $\mathrm{nm}$. 评价结果表明, $\mathrm{Ni}$ 颗粒 $4.5 \mathrm{~nm}$ 的 $\mathrm{Ni}-\mathrm{Re} / \mathrm{SiO}_{2}$ 催化剂具有最高的活性, MEA转化率高达 $85.7 \%$, EDA和PIP收率为 $66.4 \%$, 优于以往专利文献所报道的值. 结合表征结果分析, 这是由于 $\mathrm{Ni}-\mathrm{Re} / \mathrm{SiO}_{2}(4.5 \mathrm{~nm})$ 上的 $\mathrm{Ni}$ 粒径小, 分散度高, 因此 $\mathrm{Ni}$ 活性比 表面积大, 为胺化反应提供了充足的催化位点. 进一步深入研究了 $\mathrm{Ni}$ 颗粒尺寸对MEA胺化反应的影响, 发现随着 $\mathrm{Ni}$ 粒径增 加, 底物MEA的转换频率(TOF)从 $193 \mathrm{~h}^{-1}$ 增加到 $253 \mathrm{~h}^{-1}$, 表明大颗粒有利于胺化反应. 此外, 随着粒径增加, 产物中伯胺和 仲胺的摩尔比从1.0增加到2.0, 产物 $E D A$ 的 $\mathrm{TOF}_{\mathrm{EDA}}$ 值由 $63 \mathrm{~h}^{-1}$ 增加到 $119 \mathrm{~h}^{-1}$, 表明 $\mathrm{Ni}$ 粒径变化影响了 MEA胺化反应途径和 产物分布, 增大粒径有利于EDA的生成, 从而提高了产物中的伯: 仲胺之比. 实验结果证明, $\mathrm{Ni}-\mathrm{Re}_{\mathrm{SiO}}$ 催化剂粒径影响了 颗粒表面 $\mathrm{Ni}$ 的配位环境, 从而改变了表面的电子结构. 增大 $\mathrm{Ni}$ 粒径可提高面位点 $\mathrm{Ni}$ 的比例和表面电子云密度, 导致中间产 物容易从 $\mathrm{Ni}$ 表面脱附, 从而有利于促进反应初始阶段MEA与 $\mathrm{NH}_{3}$ 的胺化, 提高EDA选择性.

关键词: 颗粒尺寸效应; 乙醇胺; 胺化反应; 镍-铼/氧化硅; 转换频率

收稿日期: 2018-10-24. 接受日期: 2019-01-08. 出版日期: 2019-04-05.

*通讯联系人. 电话/传真: (0411)84379143; 电子信箱: dyj@dicp.ac.cn

\#通讯联系人. 电话/传真: (0411)84379055; 电子信箱: yanli@dicp.ac.cn

基金来源：国家自然科学基金(21273227); 中国科学院战略性先导科技专项(XDB17000000).

本文的电子版全文由Elsevier出版社在ScienceDirect上出版(http://www.sciencedirect.com/science/journal/18722067).

\section{《催化学报》为被国际期刊退稿的高质量论文开辟绿色通道}

我们注意到, 国内一些高质量、原创性的研究工作在投稿到国际期刊上时, 经常因语言和写作问题等非科学因素而被 退稿和拖延发表, 甚至会失去原创知识产权, 这个损失是巨大的, 也是非常可惜的!

众所周知, 按国际学术界的共识, 获得论文的首发权并保证拥有研究工作的原创性不在于论文发表在哪个刊物(只要 是国际ISSN挂号的), 而在于谁第一时间抢先发表了工作.

为了保护作者工作的原创性和首发知识产权, 《催化学报》编委会为具有一定原创性的论文提供快速发表的绿色通道. 对于投到国际著名期刊(如Science, Nature, Energy \& Environmental Science, Journal of the American Chemical Society, Angewandte Chemie International Edition, ACS Catalysis和Journal of Catalysis等)上催化论文的退稿, 如果其创新性较强, 学术 质量较高, 仅仅是因为语言和文章写作原因而被退稿, 《催化学报》会安排其在最近一期上抢时间发表; 如果文章原创性 较好, 不存在学风问题, 但有一些理论观点的争议、实验现象暂时无法得到完美的理论解释, 或者需要进一步补充相关实验 数据等, 本刊主编、副主编也会协助作者尽快修改和发表相关工作.

对于国际著名相关期刊的退稿, 作者需将相应的审稿意见及意见答复等材料一并提交到本刊, 以加快论文的处理速 度. 